\title{
Multiple microarray platforms utilized for hepatic gene expression profiling of GH transgenic coho salmon with and without ration restriction
}

\author{
Matthew L Rise*, Susan E Douglas ${ }^{1}$, Dionne Sakhrani ${ }^{2}$, Jason Williams ${ }^{1}$, K Vanya Ewart ${ }^{1}$, \\ Marlies Rise*, William S Davidson ${ }^{3}$, Ben F Koop ${ }^{4}$ and Robert H Devlin ${ }^{2}$ \\ Great Lakes WATER Institute, University of Wisconsin-Milwaukee, Milwaukee, Wisconsin, USA 53204 \\ ${ }^{1}$ Institute for Marine Biosciences, National Research Council, Halifax, Nova Scotia, Canada B3H 3Z1 \\ ${ }^{2}$ Aquaculture Division, Fisheries and Oceans Canada, 4160 Marine Drive, West Vancouver, British Columbia, Canada V7V 1N6 \\ ${ }^{3}$ Department of Molecular Biology and Biochemistry, Simon Fraser University, Burnaby, British Columbia, Canada V5A 1S6 \\ ${ }^{4}$ Centre for Biomedical Research, University of Victoria, Victoria, British Columbia, Canada V8W 3N5
}

(Requests for offprints should be addressed to R H Devlin; Email: devlinr@pac.dfo-mpo.gc.ca)

${ }^{\star}$ Current address is Ocean Sciences Center, Memorial University of Newfoundland, St.John's, Newfoundland, Canada A1C1S5

\begin{abstract}
The objectives of this study are to examine hepatic gene expression changes caused by GH transgenesis and enhanced growth. This is the first use of cDNA microarrays to study the influence of GH transgenesis on liver gene expression in a nonmammalian vertebrate, and the first such study using sexually immature animals. Three groups of coho salmon were examined: $\mathrm{GH}$ transgenic on full ration $(\mathrm{T}), \mathrm{GH}$ transgenic on restricted ration $(\mathrm{R})$, and control non-transgenic $(\mathrm{C})$. Specific growth rates for weight in $\mathrm{T}$ were approximately eightfold higher than in $\mathrm{C}$, and fourfold higher than in $\mathrm{R}$. Differential gene expression in $T, R$, and $C$ samples was determined using $\sim 3500$ and 16000 gene microarrays, and $R$ and $C$ samples were compared on a different $\sim 4000$ gene microarray. The use of multiple microarray platforms increased the overall proportion of the hepatic transcriptome considered in these studies. Cross-platform comparisons identified genes behaving similarly between studies. For example, genes encoding a precerebellin-like protein and complement component C3 were downregulated in $R$ relative to $C(R<C)$ in two microarray studies, and hemoglobins $\alpha$ and $\beta$ were $R>C$ in all three studies. Comparisons of informative gene lists within and between studies inferred causes of altered gene expression. For example, ten genes, including 78 kDa glucose-regulated protein, glycerol-3-phosphate dehydrogenase, hemoglobins $\alpha$ and $\beta$, and a $\mathrm{C}$-type lectin, were likely induced by $\mathrm{GH}$ transgenesis due to their presence in both $\mathrm{T}>\mathrm{C}$ and $\mathrm{R}>\mathrm{C}$ gene lists. Eleven genes, including hepcidin, nuclear protein p8, precerebellin-like, transketolase, and fatty acid-binding protein, were present in both $\mathrm{T}<\mathrm{C}$ and $\mathrm{R}<\mathrm{C}$ gene lists and were, therefore, likely suppressed by $\mathrm{GH}$ transgenesis. A large number of salmonid genes identified in these studies are involved in iron homeostasis, mitochondrial function, carbohydrate metabolism, cellular proliferation, and innate immunity. Pentose phosphate pathway genes phosphogluconate dehydrogenase, transaldolase, and transketolase, were dysregulated in $\mathrm{GH}$ transgenic samples relative to control samples. Changes in the expression of genes involved in maintaining hemoglobin levels (heme oxygenase, hemoglobins $\alpha$ and $\beta$, Kruppel-like globin gene activator, hepcidin) in R and $\mathrm{T}$ fish indicate a need for additional hemoglobin in the transgenic fish, perhaps due to higher metabolic rate required for enhanced growth.
\end{abstract}

Journal of Molecular Endocrinology (2006) 37, 259-282

\section{Introduction}

Growth hormone $(\mathrm{GH})$, synthesized largely by the pituitary gland, regulates longitudinal growth in vertebrates. GH-mediated signaling occurs in many tissues, and impacts cellular metabolism, proliferation, and differentiation (Thompson et al. 2000). In the liver, an important GH-target organ, GH regulates carbohydrate and lipid metabolism (Davidson 1987). In the last two decades, much research on GH and mammalian growth has involved the study of dwarfism (caused by chronic underproduction of GH), acromegaly (chronic overproduction of $\mathrm{GH}$ ), hypophysectomized ( $\mathrm{Hx})$ animals (surgically removed pituitary glands, modeling severe hormone deficiency), chronic and acute administration of exogenous $\mathrm{GH}$, and $\mathrm{GH}$ transgenic animals. Until recently, studies of the effects of GH on tissue gene expression have been hampered by the lack of genomic tools and methods for global gene expression profiling. The advent of DNA microarrays has allowed detailed 
analyses of the impacts of dwarfism (Tsuchiya et al. 2004), hypophysectomy (Flores-Morales et al. 2001), continuous GH treatment (Ahluwalia et al. 2004), and GH transgenesis (Olsson et al. 2003) on mammalian hepatic gene expression. The present study is the first to use cDNA microarrays to study the influence of $\mathrm{GH}$ transgenesis on liver gene expression in a non-mammalian vertebrate, and the first such study using sexually immature animals.

GH transgenic salmonids experience extraordinary rates of growth in their 1st year, well before the onset of sexual maturation (Devlin et al. 1994, 2001, $2004 a$ ). Feed availability has a profound influence on growth rates of sexually naïve GH transgenic coho salmon (Oncorhynchus kisutch). Our objectives are to study the consequences of growth, GH transgenesis, and ration level, through comparisons of global hepatic gene expression data from three groups of sexually immature coho salmon: GH transgenic on a full ration (group $\mathrm{T}$ ), GH transgenic on a restricted ration (group $\mathrm{R}$ ), and control non-transgenic (group $\mathrm{C}$ ). We have conducted three experiments, each in a different laboratory and using different cDNA microarray platforms containing primarily Atlantic salmon (Salmo salar) sequences. The microarray platforms used in this research were a 3554 gene $(3 \cdot 5 \mathrm{~K})$ microarray developed by the Genomic Research on Atlantic Salmon Project (GRASP; Rise et al. 2004b), a 16006 gene (16K) GRASP microarray (von Schalburg et al. $2005 b$ ), and a 4104 gene (4K) microarray developed by the Institute for Marine Biosciences (IMB; Ewart et al. 2005). Heterologous hybridizations indicate that Atlantic salmon cDNA microarrays are effective tools for global gene expression studies involving any salmonid species (Rise et al. 2004b, von Schalburg et al. 2005b). The use of multiple microarray platforms increased the number of different genes, and therefore the proportion of the liver transcriptome, considered in the present study. Cross-platform comparisons confirmed results by identifying genes present in similar informative gene lists between microarray studies, and comparisons within and between studies inferred biological causes of altered gene expression. The functional annotations of informative genes, and the pertinent literature, point to hepatic molecular pathways and biological functions altered by $\mathrm{GH}$ transgenesis, growth, and/or ration restriction.

\section{Materials and methods}

\section{Aquaculture, sampling, and growth assessment}

Coho salmon examined in this study were derived from the Chehalis River, which is a main tributary river of the
Fraser River in southwestern British Columbia, Canada. All fish culture was conducted at Fisheries and Oceans Canada's West Vancouver Laboratory, which is a non-commercial contained research facility specially designed to prevent the escape of genetically modified fish to the natural environment. GH transgenic coho salmon were initially produced by microinjecting a GH-gene construct (OnMTGH1) into the eggs from wild parents from the Chehalis River (Devlin et al. 1994). The strain used in the present study (M77) is stable and shows highly enhanced growth rates relative to wild-type sibling controls (Devlin et al. 2004a).

The objectives of the present study are to examine gene expression changes caused by GH transgenesis and enhanced growth. It is possible that there are both direct effects of GH transgenesis and indirect effects, which arise as a consequence of greatly accelerated growth. To separate these effects, three types of fish were examined in the present study: group $\mathrm{T}$, transgenic fish reared on a full ration (which fully satiates their voluntary intake of food) for 9 months; group C, control non-transgenic coho salmon reared on a full ration for 21 months; and group R, transgenic salmon reared for 21 months on a restricted ration equivalent (per kilogram body weight) to that consumed by control salmon on a full ration. $\mathrm{R}$ salmon were pair fed in parallel with a group of $\mathrm{C}$ salmon of the same biomass, and were daily provided with the same amount of food consumed by the $\mathrm{C}$ group. Thus, group $\mathrm{T}$ grew at the very rapid rate typical of this $\mathrm{GH}$ transgenic strain, whereas groups $\mathrm{C}$ and $\mathrm{R}$ grew at similar rates typical of non-transgenic salmon. Use of fish of differing ages of $\mathrm{T}$ and $\mathrm{C}$ fish was necessary to ensure that fish were at the same developmental stages at the time of analysis. Comparisons of age-matched groups growing at their maximum growth rates are inappropriate due to the very large difference in size, which rapidly occurs between transgenic and nontransgenic individuals resulting in fish of different developmental stages (i.e. after some 4 months of growth, non-transgenic fish are still fry and are adapted for fresh water growth, whereas GH transgenic salmon are smolts, which are adapted for marine conditions). Age-matched samples at the same developmental stage have been generated by restricting the feeding of transgenic fish (group R), but these fish will differ due to effects from ration limitation. Thus, elucidation of the consequences of growth, GH transgenesis, and ration level requires assessment of all three groups ( $\mathrm{T}$, $\mathrm{C}$, and $\mathrm{R}$ ). Comparison of groups $\mathrm{T}$ and $\mathrm{C}$ salmon allows examination of effects of both growth and GH transgenesis, comparison of groups $\mathrm{T}$ and $\mathrm{R}$ salmon reveals effects arising indirectly from growth rate and/or ration restriction, and comparison of groups $\mathrm{C}$ and $\mathrm{R}$ allows identification of effects of $\mathrm{GH}$ transgenesis and/or ration restriction. 
Group $\mathrm{T}$ transgenic salmon used in this study were $\mathrm{F}_{5}$ generation progeny (year 2001 brood) produced by crossing a father homozygous for the transgene insert with five wild females derived from the Chehalis River. These crosses stably produce $100 \%$ transgenic hemizygous progeny (Devlin et al. 2004a). Group C were non-transgenic salmon (year 2000 brood) produced by crossing wild salmon sires with five wild females. Group $\mathrm{R}$ transgenic salmon were $\mathrm{F}_{4}$ progeny (year 2000 brood) derived as for group $\mathrm{T}$, except using the same females as in group $\mathrm{C}$, but homozygous fathers from a previous year class. Group R salmon were reared on a restricted, control level, ration throughout the pre-experiment period. The variance associated with intrafamily growth rates is very small relative to the difference in growth observed between transgenic and non-transgenic salmon. Nevertheless, transgenic strain M77 has been maintained in an otherwise wild genetic background by continuous backcrossing to wild fish. Thus, the transgenic and non-transgenic strains should on average differ genetically only at the transgenic locus. All fish groups were initially incubated in Heath trays during embryonic development followed by culture under parallel conditions in oxygen-saturated fresh well water at $10{ }^{\circ} \mathrm{C}$ with a flow rate in excess of $11 / \mathrm{min} / \mathrm{kg}$ and a fish density $<5 \mathrm{~kg} / \mathrm{m}^{3}$. Stage-specific feeds were obtained from Skretting Canada (Vancouver, BC, Canada).

During the pre-sample period (August 21, 2002), 11 control non-transgenic $(\mathrm{C}), 11$ ration-fed $\mathrm{GH}$ transgenic $(\mathrm{R})$, and 11 full ration $\mathrm{GH}$ transgenic $(\mathrm{T})$ post-smolt coho salmon were identified with unique passive integrated transponder tags implanted in their i.p. space, and placed in separate $200 \mathrm{l}$ tanks and fed twice daily. $\mathrm{C}$ fish were fed to satiation, $\mathrm{R}$ fish were fed the same amount of food as $\mathrm{C}$ salmon (one $\mathrm{R}$ fish died and ration was adjusted accordingly), and $\mathrm{T}$ fish were fed to satiation. Length-specific growth rates $\left(\mathrm{SGR}_{\mathrm{L}}\right)$ and weight-specific growth rates $\left(\mathrm{SGR}_{\mathrm{W}}\right)$ were calculated using the equation, $\mathrm{SGR}=\left[\ln \left(x_{2} / x_{1}\right) /\left(t_{2}-t_{1}\right)\right] \times 100$, with $x_{1}$ as length or weight at time $t_{1}$, and $x_{2}$ as length or weight at time $t_{2}$ (Fig. 1; see Table S1 in Supplementary data at http://jme.endocrinology-journals. org/content/vol37/issue2/). One-way ANOVA was used to assess differences in $\mathrm{SGR}_{\mathrm{L}}$ and $\mathrm{SGR}_{\mathrm{W}}$. Tukey post-hoc tests were used for pairwise comparisons of growth rates for the $\mathrm{C}, \mathrm{R}$, and $\mathrm{T}$ treatment groups, and a significance level of $P=0.05$ was utilized.
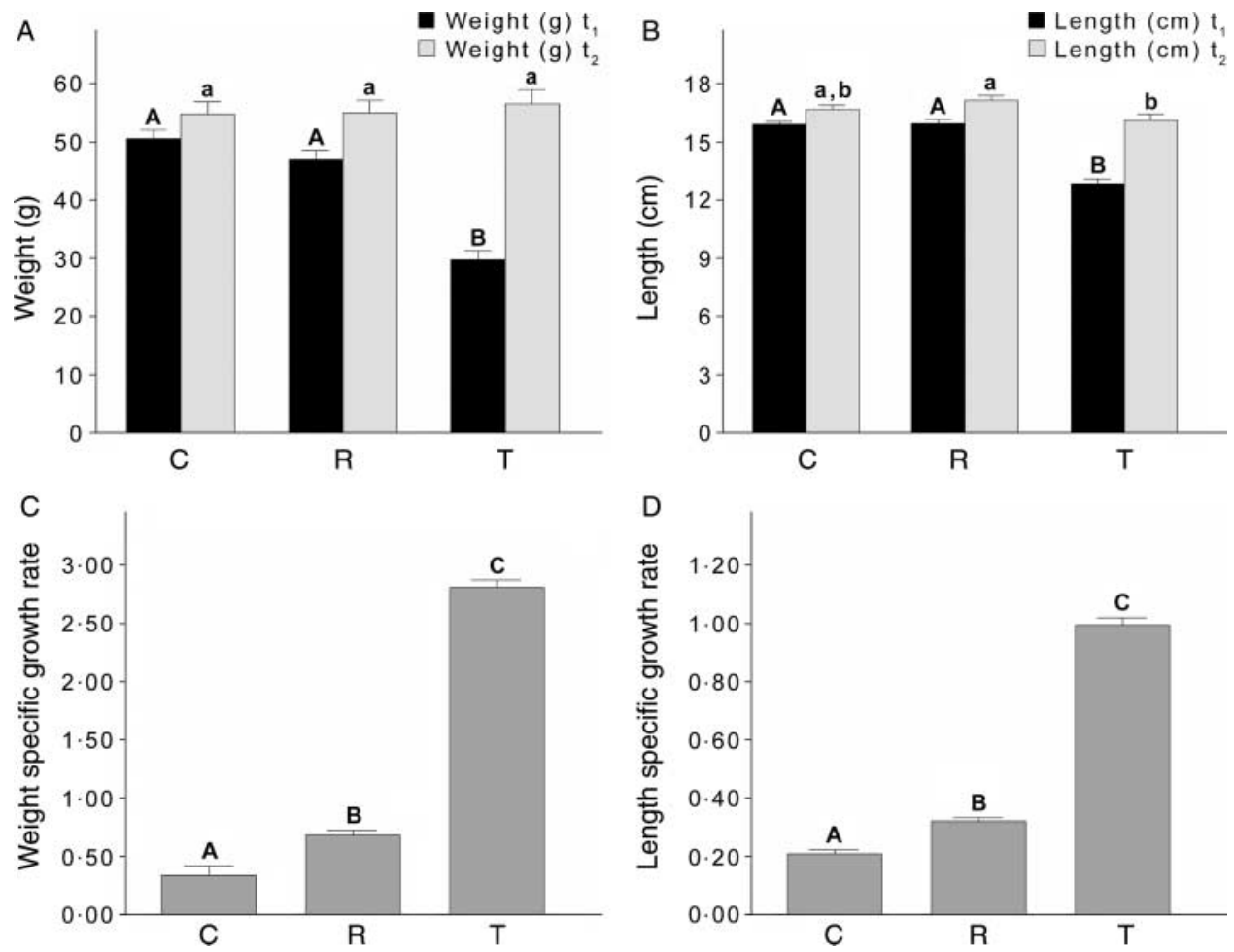

Figure 1 Growth data for control non-transgenic $(C)$, ration-fed $\mathrm{GH}$ transgenic $(\mathrm{R})$, and full ration GH transgenic (T) year class 1 fish at times $t_{1}$ (August 21, 2002) and $t_{2}$ (September 13, 2002).

(A) Average $\mathrm{C}, \mathrm{R}$, and T weights $(\mathrm{g})$ at $t_{1}$ and $t_{2}$. (B) Average $\mathrm{C}, \mathrm{R}$, and T lengths $(\mathrm{cm})$ at $t_{1}$ and $t_{2}$. (C) Average C, R, and T weight-specific growth rates. (D) Average C, R, and T length-specific growth rates. Error bars $=$ S.E.M. Within each graph, identical letters (upper case for $t_{1}$ data, lower case for $t_{2}$ data) indicate no significant difference $(P>0.05)$ between the $\mathrm{C}, \mathrm{R}$, and $\mathrm{T}$ treatment groups. 
Following anesthetization in tricane-methanesulphonate $(100 \mathrm{mg} / \mathrm{l}$ with $100 \mathrm{mg} / \mathrm{l}$ sodium bicarbonate), fish were sampled for weight and length, and weight-matched fish from each group were euthanized by a sharp blow to the head, and tissues rapidly removed by team dissection. Tissues were flash frozen in liquid nitrogen and stored at $-75{ }^{\circ} \mathrm{C}$ until RNA extraction.

\section{Microarray analysis}

Three different Atlantic salmon microarray platforms were utilized in this study: a 3.5K GRASP microarray, $16 \mathrm{~K}$ GRASP microarray, and 4K IMB microarray. Differential gene expression in $\mathrm{T}, \mathrm{R}$, and $\mathrm{C}$ liver samples was determined using the $3.5 \mathrm{~K}$ and 16K GRASP microarrays, and $\mathrm{R}$ and $\mathrm{C}$ samples were compared on the IMB microarray. Construction and initial testing of the GRASP microarrays described previously (Rise et al. 2004a,b, von Schalburg et al. 2005a,b). Briefly, clones were stringently selected from an expressed sequence tag (EST) database containing approximately 80000 sequences derived from over 30 high-complexity salmonid cDNA libraries at the time the $3 \cdot 5 \mathrm{~K}$ microarray was designed and built, and over 300000 sequences from over 175 high-complexity salmonid cDNA libraries at the time the $16 \mathrm{~K}$ microarray was constructed. Inserts were amplified by PCR, cleaned, and printed as double, side-by-side spots on ez-rays aminosilane slides (Matrix) in $3 \times$ SSC. Arabidopsis thaliana cDNAs were spotted on each microarray (Rise et al. 2004b, von Schalburg et al. 2005b) and used for thresholding (see Supplemental data at http://jme. endocrinology-journals.org/content/vol37/issue2/).

Construction of the IMB microarray has been described previously (Ewart et al. 2005). Briefly, 4104 clones were selected from four non-normalized salmonid cDNA libraries from liver, head kidney, macrophage, and spleen, as well as cDNA libraries constructed by suppression subtraction hybridization from the same tissues infected by the pathogen Aeromonas salmonicida. cDNAs were amplified by PCR, purified, resuspended in $\mathrm{dH}_{2} \mathrm{O}$, and spotted in duplicate on Gap II glass slides (Corning, Corning, NY, USA) in 50\% DMSO. The entire array of 8208 spots was reprinted on the lower half of the slide. Twofold dilutions of a plasmid encoding chlorophyll synthetase G4 from $A$. thaliana were included at the bottom of each sub-array to serve as internal controls.

\section{RNA isolation, and microarray hybridization and analysis}

Microarray experiments were designed to comply with Minimum Information About a Microarray Experiment (MIAME) guidelines (Brazma et al. 2001). For GRASP microarrays, all scanned microarray TIF images and quantified raw data files are available as online supplemental data at http://web.uvic.ca/cbr/grasp. Corresponding data for IMB microarrays are available as online supplemental data at http://www.imb.nrc.gc.ca/ projects/salmonlivergeneexp/index_e.php. In addition, microarray TIF images and raw data (ImaGene or QuantArray files) have been deposited in gene expression omnibus (GEO; http://www.ncbi.nlm.nih. gov/geo/). For the $3.5 \mathrm{~K}$ GRASP microarray experiment, the GEO platform accession number is GPL966; the GEO sample accession numbers are GSM44847 (slide DD035·038), GSM44848 (DD035·040), GSM44849 (DD035·041), GSM44988 (DD035·042), GSM44989 (DD035·043), GSM44990 (DD035·044), GSM44991 (DD035.046), GSM44992 (DD035.047), and GSM44993 (DD035.048); the GEO series accession number is GSE2388. For the 16K GRASP microarray experiment, the GEO platform accession number is GPL2989; the GEO sample accession numbers are GSM78638 (slide EB017·061), GSM78641 (EB017·062), GSM78664 (EB017·063), GSM78665 (EB017·064), GSM78666 (EB017·065), and GSM78667 (EB017·066); the GEO series accession number is GSE3477. For the $4 \mathrm{~K}$ IMB microarray experiment, the GEO platform accession number is GPL2844; the GEO sample accession numbers are GSM78628 (slide 12605187-L-n-bottom), GSM78629 (slide 12605533-L-n-top), GSM78630 (slide 12605532-Ln-bottom), GSM78631 (slide 12605532-L-n-top), GSM78632 (slide 12841776-L-n-bottom), GSM78633 (slide 12841776-L-n-top), GSM78634 (slide 12841777-Ln-bottom), and GSM78635 (slide 12841777-L-n-top); the GEO series accession number is GSE3475.

\section{GRASP microarrays}

GRASP microarray studies were conducted using liver samples from fish of year class 1 (Fig. 2A and B). To minimize technical variability within a study, all targets were synthesized in one round, and all hybridizations were conducted simultaneously on slides from a single batch (DD035 for 3.5K study and EB017 for 16K study). Total RNA was individually prepared from flash-frozen adult liver tissues using TRIzol reagent and methods (Invitrogen). RNA from each fish was quantified and quality-checked by spectrophotometer and agarose gel respectively. The microarray experiments used pooled RNA templates (pooled $\mathrm{C}$, pooled $\mathrm{R}$, and pooled $\mathrm{T}$; Fig. 2A and B), and each individual fish contributed an equal quantity of high-quality total RNA to a pool. Since the microarray studies involved pooled RNA samples, they did not provide information on biological variability of expression of informative genes. However, individual fish total RNA samples contributing to pools were archived at $-80^{\circ} \mathrm{C}$, and used as templates in the quantitative reverse transcription-PCR (QPCR) validation of a selection of microarray-identified genes 


\title{
Overview of microarray experimental designs and results
}

\author{
A. Study 1 platform: GRASP $\sim 3500$ gene (3.5K) cDNA microarray \\ samples: $\mathbf{C}$ (control non-transgenic), $\mathbf{R}$ (ration-fed $\mathrm{GH}$ transgenic), \\ and $\mathrm{T}$ (full ration $\mathrm{GH}$ transgenic) livers from fish of year class 1 \\ 3.5K R < C in all 3 slides: 10 different transcripts (Table S5) \\ 3.5K R > C in all 3 slides: 17 different transcripts (Table S6)

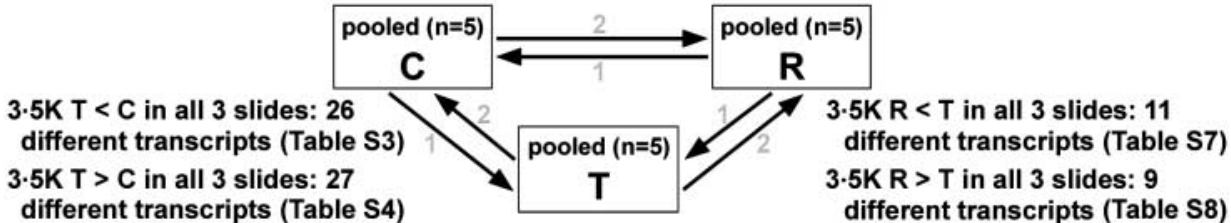

\section{B. Study 2 platform: GRASP $\sim 16,000$ gene (16K) cDNA microarray} samples: C, R, and T livers from fish of year class 1

$16 K R<C$ in both slides: 16 different transcripts (Table S11)

16K $R>C$ in both slides: 3 different transcripts (Table S12)

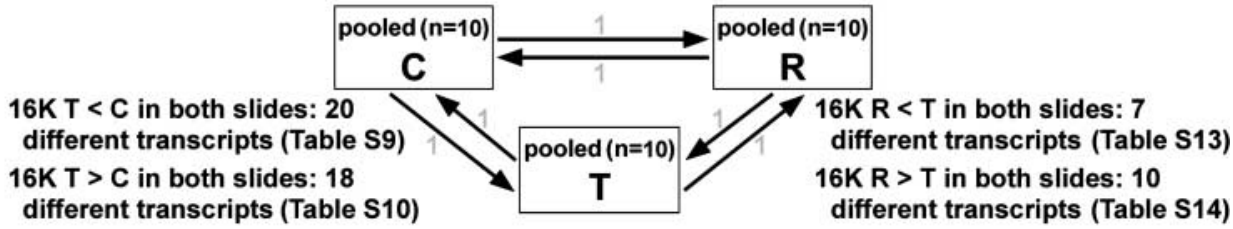

\section{Study 3 platform: IMB $\sim \mathbf{4 0 0 0}$ gene (4K) cDNA microarray} samples: $C$ and $R$ livers from fish of year class 2

\begin{abstract}
IMB significantly $R<C$ : 9 different transcripts
\end{abstract} (Table S15)

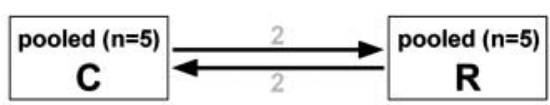

IMB significantly $R>C$ : 9 different transcripts (Table S16)

Figure 2 Overview of microarray experimental designs and results (results compiled from Tables S3-S16 in Supplementary data at http://jme.endocrinology-journals.org/content/vol37/issue2/ ).

(A) 3.5K GRASP microarray study. (B) 16K GRASP microarray study. (C) 4K IMB microarray study. Arrows between samples symbolize microarrays with the base of each arrow on the Cy3-labeled target and the arrowhead on the Cy5-labeled target. Numbers of replicates are indicated next to arrows. Microarray features having identical top (most negative E-value) BLASTX hits are considered to be the same transcript. Summary data are shown adjacent to $T$ versus $C, R$ versus $C$, and $T$ versus $R$ sample comparisons. $\mathrm{C}$, control non-transgenic; $\mathrm{R}$, ration-fed $\mathrm{GH}$ transgenic; $\mathrm{T}$, full ration $\mathrm{GH}$ transgenic.

(Fig. 3). The QPCR data, therefore, reveal biological variability of expression levels for genes validated in this manner. Microarray experimental design (Fig. 2A and B) involved three comparisons ( $\mathrm{C}$ versus $\mathrm{R}, \mathrm{C}$ versus $\mathrm{T}$, and $\mathrm{R}$ versus $\mathrm{T}$ ), each run in triplicate (two replicates and one dye flip) for the $3.5 \mathrm{~K}$ study, or duplicate (one microarray and a dye flip) for the 16K study. The microarray experiments included only technical replicates (i.e. with averaged biological variation contained within technical replicates), while QPCR experiments included both technical and biological replicates. Microarray hybridizations were performed using the 3DNA Array 50 Expression Array Detection Kit and instructions (Genisphere, Inc., Hatfield, PA, USA). The Array 50 instruction manual, which includes an explanation of the chemistry involved in the Array 50 labeling system, is available online at http://www.genisphere.com/pdf/array50v2_10_19_ 04.pdf. Briefly, $20 \mu \mathrm{g}$ total RNA (pooled C, pooled R, or pooled $T)$ were reverse transcribed using oligo $d(T)$ primers with unique 5-prime sequence overhangs for the Cy3 or Cy5 labeling reactions. Microarrays were prepared for hybridization by washing $2 \times 5 \mathrm{~min}$ in $0 \cdot 1 \%$ SDS, washing $5 \times 1 \mathrm{~min}$ in MilliQ $\mathrm{H}_{2} \mathrm{O}$, immersing $3 \mathrm{~min}$ in $95^{\circ} \mathrm{C}$ MilliQ $\mathrm{H}_{2} \mathrm{O}$, and drying by centrifugation ( $5 \mathrm{~min}, 2000$ r.p.m. in $50 \mathrm{ml}$ conical tube). Microarray hybridizations were run in the dark under HybriSlips hybridization covers (Grace Biolabs, Bend, OR, USA) in slide hybridization chambers (Corning, Corning, NY, USA) submerged in a $48^{\circ} \mathrm{C}$ water bath. The coho salmon liver cDNAs were hybridized to the salmonid cDNA microarray in a formamide-based buffer ( $25 \%$ formamide, $4 \times \mathrm{SSC}$, $0.5 \%$ SDS, $2 \times$ Denhardt's solution) for $16 \mathrm{~h}$ at $48^{\circ} \mathrm{C}$. 
A Iron-sulfur cluster assembly $\mathrm{U} 2$ is down-regulated in both $\mathrm{T}$ and $\mathrm{R}$ relative to $\mathrm{C}$
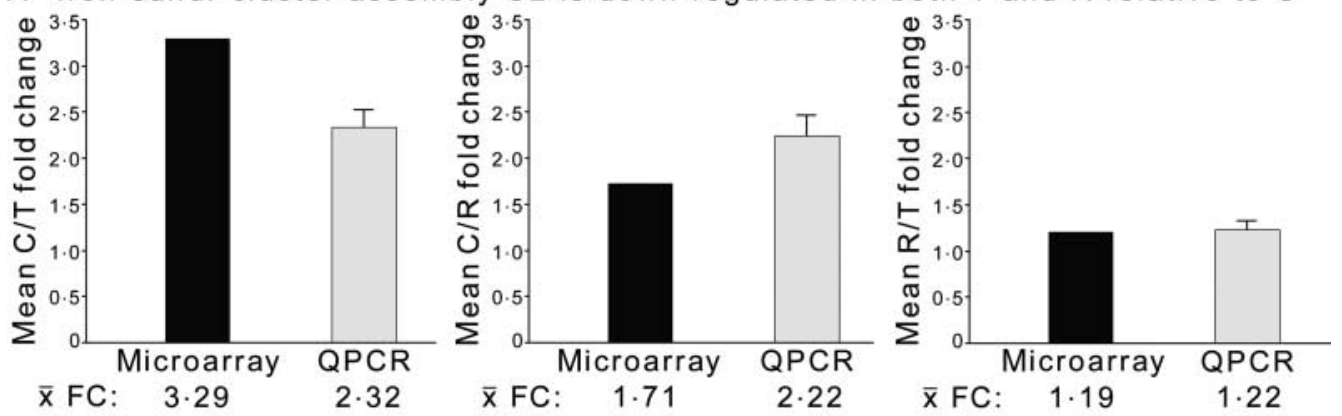

B Hepcidin antibacterial peptide is down-regulated in both $T$ and $R$ relative to $C$
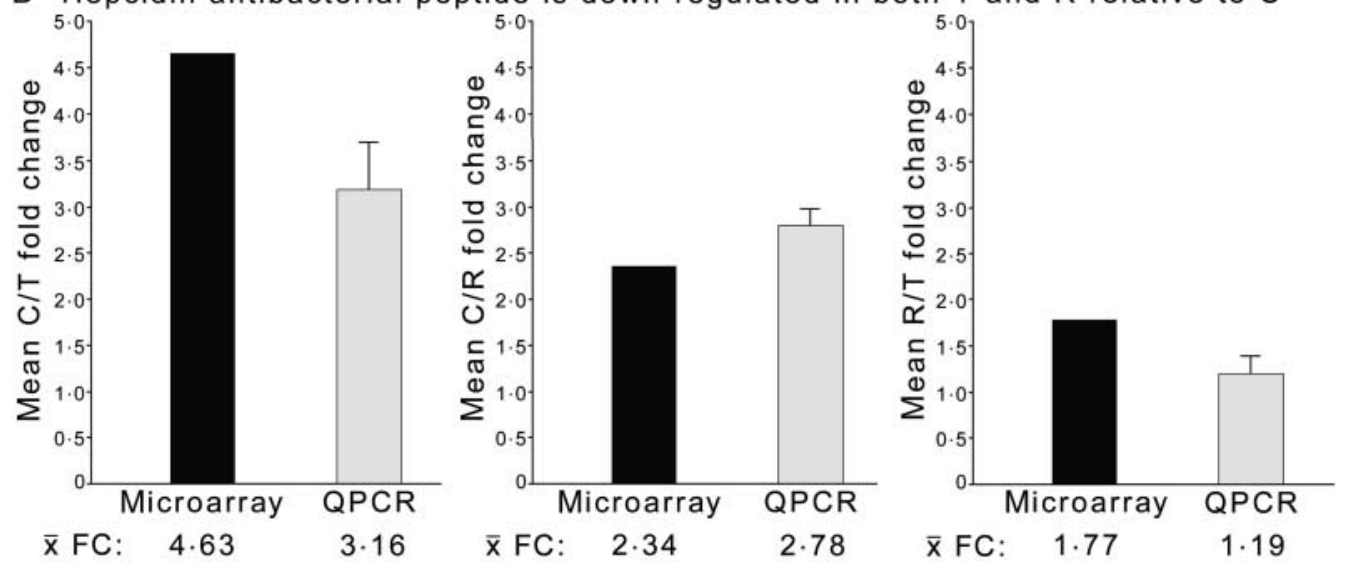

X FC: $\quad 1.77$

$1 \cdot 19$

C Transaldolase is down-regulated in $\mathrm{R}$ relative to both $\mathrm{T}$ and $\mathrm{C}$
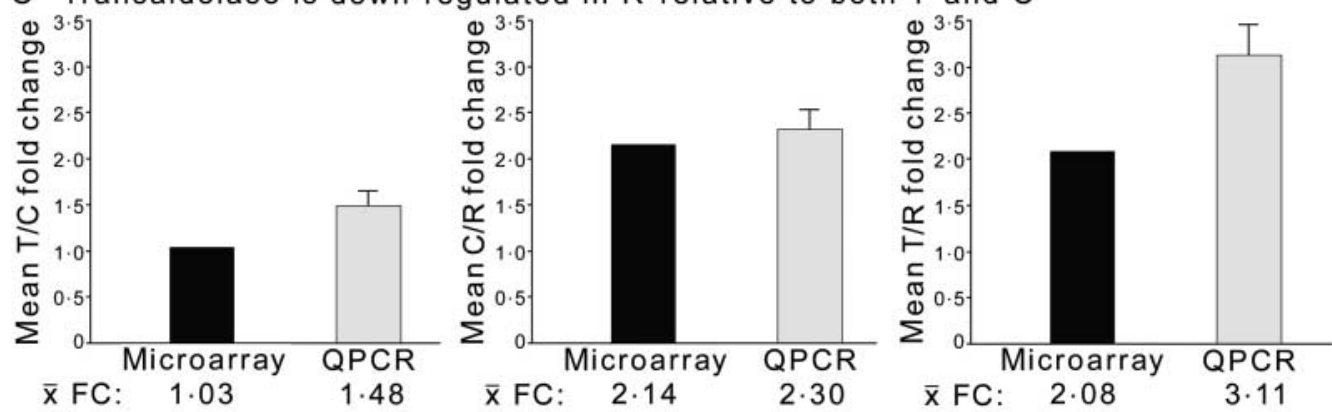

D Phosphogluconate dehydrogenase is down-regulated in $\mathrm{R}$ relative to $\mathrm{T}$ and $\mathrm{C}$
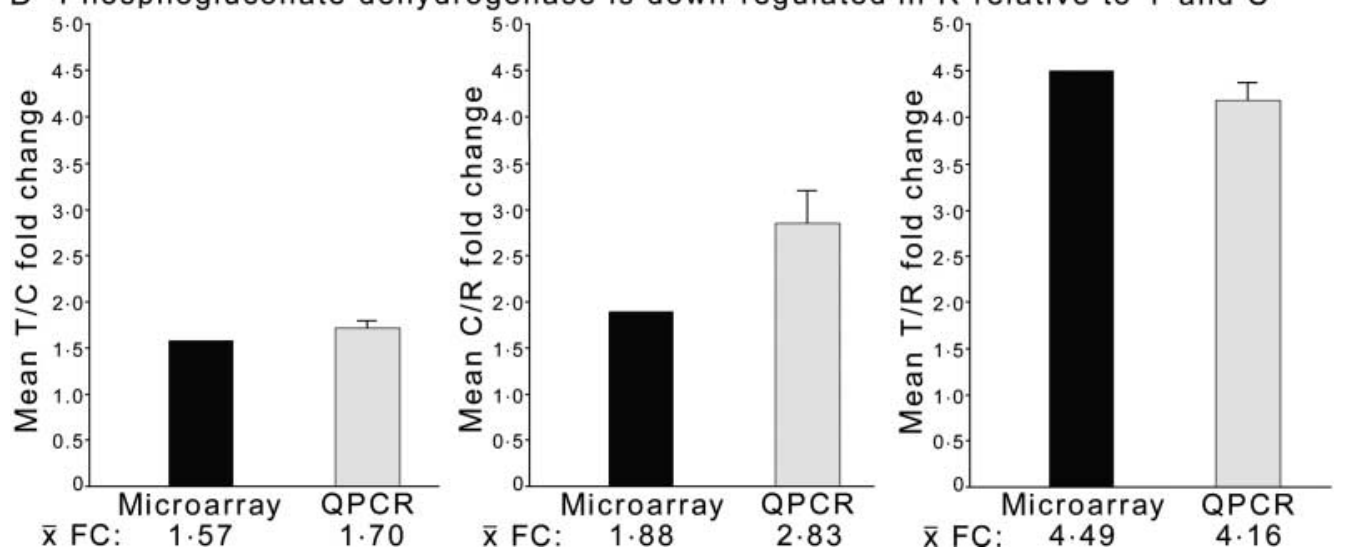
Coverslips were floated off at $48^{\circ} \mathrm{C}$ in $2 \times$ SSC, $0 \cdot 1 \%$ SDS buffer, and arrays were washed once for $10 \mathrm{~min}$ in $2 \times \mathrm{SSC}, 0 \cdot 1 \% \mathrm{SDS}$ at $48^{\circ} \mathrm{C}$, twice for $5 \mathrm{~min}$ in $2 \times \mathrm{SSC}$, $0 \cdot 1 \%$ SDS at room temperature (RT), twice for $5 \mathrm{~min}$ in $1 \times$ SSC at RT, and twice for $5 \mathrm{~min}$ in $0 \cdot 1 \times \mathrm{SSC}$ at RT, and dried by centrifugation as before. The $\mathrm{Cy} 3$ and $\mathrm{Cy} 5$ threedimensional fluorescent molecules (3DNA capture reagent, Genisphere) were hybridized to the bound cDNA on the microarray in a formamide-based buffer (25\% formamide, $4 \times$ SSC, $0.5 \%$ SDS, $2 \times$ Denhardt's solution) for $3 \mathrm{~h}$ at $48^{\circ} \mathrm{C}$, and washed and dried as before.

Fluorescent images of hybridized arrays were acquired immediately at $10 \mu \mathrm{m}$ resolution using ScanArray Express (PerkinElmer, Wellesley, MA, USA) . The same laser power (90\%) and photomultiplier tube (PMT) settings were used for all slides in each study (3.5K study Cy3 PMT 75, Cy5 PMT 65-67; 16K study Cy3 PMT 78-80, Cy5 PMT 72-76). Fluorescent intensity data were extracted from TIF images using ImaGene (BioDiscovery, El Segundo, CA, USA; 3.5K study) or QuantArray software (PerkinElmer; 16K study). Quality statistics were compiled in Excel (see Table S2 in Supplementary data at http://jme.endocrinologyjournals.org/content/vol37/issue2/), and data transformation (background correction, and setting background corrected values $<0 \cdot 01$ to $0 \cdot 01$ ), normalization (Lowess), and analysis (formation and comparison of fold change gene lists) were performed in GeneSpring (Silicon Genetics Agilent Technologies, Palo Alto, CA, USA). In the GRASP microarray studies, transcripts with greater than twofold difference in expression between RNA samples of a given comparison (i.e. pooled $\mathrm{T}$ versus pooled $\mathrm{C}$ ) in all slides of a study are reported in Supplementary data, Tables S3-S14 (see http://jme.endocrinology-journals.org/ content/vol37/issue2). These relatively strict criteria for identifying reproducibly informative transcripts were utilized to minimize false positives occurring due to dye bias and technical variability.

\section{IMB microarrays}

The IMB microarray study was conducted using liver samples from fish of year class 2 (Fig. 2C). mRNA, prepared from adult liver tissues preserved in RNALater (Ambion, Austin, TX, USA) using the FastTrack kit (Invitrogen), was quantified and quality-checked by spectrophotometer and agarose gel. Microarray target synthesis used $100 \mathrm{ng}$ pooled $\mathrm{C}$ or pooled $\mathrm{R}$ mRNA template, and each pool contained approximately equal quantities from five individual fish. All experiments were conducted in quadruplicate (two replicates and two dye flips). The top array from each slide was scanned and analyzed separately from the bottom array, yielding eight data sets and 16 possible spots for each gene. Preparation of cDNA using the SuperSmart PCR cDNA Synthesis Kit (BD Biosciences, San Jose, CA, USA), amplification using the Advantage 2 PCR Kit (BD Biosciences), labeling of cDNA with Cy3- and Cy5-dCTP (Amersham), hybridization, and scanning were performed as previously described (Ewart et al. 2005). Normalization and data analysis were carried out using the GeneTraffic software (Iobion Informatics, La Jolla, CA, USA). Background fluorescence was subtracted from the spot intensities and spots were flagged and removed from the data set, if the signal to background ratio was $<1$, the signal to average background ratio was $<1$, or the signal intensity was $<1000$. Data were normalized on a sub-grid basis using both locally weighted non-linear regression (Lowess) and intensity-based methods. Differentially regulated genes were identified using the following filter: normalized $\log 2$ ratios of spots $>0.9$ or $<-0.9$ in the arrays using RNAs from $\mathrm{R}$ versus $\mathrm{C}$ fish, eight or more (out of 16) unflagged spots contributing to this assessment, and an overall coefficient of variation for that spot of $<0 \cdot 3$. Since biologically significant changes in gene expression may not be greater than twofold or $<0 \cdot 5$-fold, the nonparametric significance analysis of microarrays (SAM; Tusher et al. 2001) method was carried out on the normalized data to identify differentially regulated genes based on their changes in expression in relation to the s.D. for multiple measurements. The false discovery rate was set at $1 \%$, meaning that, on average, $1 \%$ of the genes would be classified incorrectly using this method. Genes were identified as up- or downregulated only if they were identified using both the filter and SAM methods.

\section{Real-time quantitative reverse transcription (RT)-PCR (QPCR)}

Validating QPCRs were run using RNA templates from the livers of individual fish in year class 1 . Total RNA was prepared from flash-frozen $\mathrm{C}$, $\mathrm{R}$, and $\mathrm{T}$ coho livers using TRIzol reagent and methods (Invitrogen). For each individual, $250 \mathrm{ng}$ RNA were reverse transcribed using $31.25 \mathrm{ng}$ oligo $\mathrm{d}(\mathrm{T})_{16}$ primer. Reverse transcription

Figure 3 Real-time quantitative RT-PCR (QPCR) validation of 3.5K GRASP microarray results for four transcripts of interest ((A) iron-sulfur cluster assembly U2; (B) hepcidin antibacterial peptide; (C) transaldolase 1; (D) phosphogluconate dehydrogenase) normalized to ubiquitin. Mean ratios (fold changes) are shown. Numbers of replicates: microarrays, $n=3$ slides (two identical replicates and one dye flip) per comparison (e.g. pooled T versus pooled C; since these are technical replicates with pooled samples, rather than biological replicates, microarray data error bars are not included); QPCR, $n=2$ reactions per individual fish, 11 individual $C$ and T fish and ten individual $\mathrm{R}$ fish examined. Error bars =s.E.M. The identities of the QPCR amplification products were confirmed by sequencing. $\mathrm{C}$, control non-transgenic; R, ration-fed GH transgenic; T, full ration $\mathrm{GH}$ transgenic. 
reactions included $5 \mathrm{U}$ RNase inhibitor, $500 \mu \mathrm{M}$ dNTPs, $5.5 \mathrm{mM} \mathrm{MgCl}_{2}$, and $15.625 \mathrm{U}$ MultiScribe Reverse Transcriptase with $1 \times$ TaqMan RT buffer (TaqMan Reverse Transcription Reagents Kit, Applied Biosystems, Foster City, CA, USA). Thermal cycling parameters for reverse transcription reactions were as follows: $25^{\circ} \mathrm{C}$ for $10 \mathrm{~min}, 48^{\circ} \mathrm{C}$ for $30 \mathrm{~min}, 95^{\circ} \mathrm{C}$ for $5 \mathrm{~min}$. First-strand cDNAs were diluted 1:3 and used as templates for QPCR analysis.

QPCR used two PCR primers per gene and SYBR Green I dye. Transcripts of interest and a normalizer gene were selected from the results of microarray experiments. For both the $3.5 \mathrm{~K}$ and $16 \mathrm{~K}$ GRASP studies, five different microarray features with ESTs identified as ubiquitin (top BLASTX hit: Oncorhynchus mykiss ubiquitin, accession number BAA88568) had normalized Cy5/Cy3 ratios between 0.5 and 2.0 on all slides. Ubiquitin was not dysregulated by $\mathrm{GH}$ transgenesis and/or ration restriction, and was therefore an appropriate normalizer gene for QPCR validation of microarray results. Primer pairs for transcripts of interest and ubiquitin were designed from alignments of the transcripts of interest and other available homologous sequences in GenBank using Primer Express software (Applied Biosystems) and the following guidelines: product size $150-250 \mathrm{bp}, T_{\mathrm{m}} 60 \pm$ $1{ }^{\circ} \mathrm{C}$, and at least two of the $3^{\prime}$ terminal six bases $\mathrm{G} / \mathrm{C}$. For each gene, sequences of the forward and reverse QPCR primers respectively, are as follows: ubiquitin, 5'-CAACAGCGTCTGATCTTCGC-3' ${ }^{\prime}, 5^{\prime}$-TTTGTCACAGTTGTACTTCTGGGC-3'; iron-sulfur cluster assembly U2 (ISCU2), 5'-AGCTTCATCACATCTCCACAAGC-3' 5'-CAAGAAGGTAGTGGACCACTATGAGAA-3'; hepcidin antibacterial peptide, 5'-GTTGGAAGCTTTGA CAGTCCAGTT-3', 5'-AGAAGCCACAGCCAATGTTGT3'; phosphogluconate dehydrogenase, 5'-CACCGTGGCCTGTCCAGT-3', 5'-ACCACCGCCTTGTCCTTCTA-3'; and transaldolase 1, 5'-GCCGTCAGAGAGCTTCTCCA3', 5'-AGAGCTGAGCAAAGACCACAGC-3'. Reactions (20 $\mu \mathrm{l}$ total volume) containing $4 \mu \mathrm{l}$ diluted template, $300 \mathrm{nM}$ each primer (with the exception of transaldolase at $50 \mathrm{nM}$ ), and $1 \times$ SYBR Green PCR Master Mix (Applied Biosystems), were run in duplicate using an ABI Prism 7000 Sequence Detection System (Applied Biosystems) and the following cycling parameters: $95^{\circ} \mathrm{C}$ for $10 \mathrm{~min}$, then 40 cycles of $\left(95^{\circ} \mathrm{C}\right.$ for $15 \mathrm{~s}, 60^{\circ} \mathrm{C}$ for $\left.1 \mathrm{~min}\right)$. Controls (no template) were run for all primer pairs. Standard curves were generated by template dilution, with $>$ 98.95\% efficiency, for all primer pairs for relative quantitation by the ABI Prism 7000 Sequence Detection System.

Duplicate data (threshold cycle, or $C_{\mathrm{t}}$, values) for each transcript of interest and for each individual were first normalized to ubiquitin (individual $C_{\mathrm{t}}$ value minus average ubiquitin $C_{\mathrm{t}}$ value for the same template). Data (normalized $C_{\mathrm{t}}$ values) from control non-transgenic, ration-fed transgenic, and full ration transgenic templates were compared (converted to fold differences) in Excel using the relative quantification method (Pfaffl 2001) and assuming 100\% efficiencies. All $C_{\mathrm{t}}$ values and calculations are available online (Supplementary data, Tables S18-S22; http://jme. endocrinology-journals.org/content/vol37/issue2/). Melting curves for the QPCR products for all transcripts of interest and ubiquitin showed single peaks. Endpoint analysis on agarose gels showed a strong, single band of the expected size for the iron-sulfur cluster assembly U2 primers, but the primers for ubiquitin and the remaining transcripts of interest showed two bands of the appropriate size, as may be anticipated for transcripts derived from a tetraploid genome such as salmon. The two bands were extracted from the gel and sequenced. The resulting sequences matched one another and the EST sequence used for primer design.

\section{Results}

\section{Growth characteristics of C, R, and T fish}

The following growth data pertain to the year class analyzed using the $3 \cdot 5 \mathrm{~K}$ and 16K GRASP microarrays (Figs 1 and 2; See Supplementary data, Tables S1 and S2 at http://jme.endocrinology-journals.org/content/ vol37/issue2/). At the start of the pre-experiment period $\left(t_{1}=\right.$ August 21,2002$)$, for both mean weights and length, $\mathrm{C}$ and $\mathrm{R}$ salmon did not differ but both were larger than $\mathrm{T}$ salmon (Fig. 1A and B; See Supplementary data, Table S1). The salmon in all treatment groups were re-measured for length and weight (Fig. 1A and B; See Supplementary data, Table S1) on September 13, $2002\left(t_{2}\right)$, at which time T salmon had grown to the same weight as $\mathrm{C}$ and $\mathrm{R}$ salmon and the same length as $\mathrm{C}$ salmon, but were slightly shorter than $\mathrm{R}$ salmon (Fig. 1A and B; See Supplementary data, Table S1). Specific growth rates over the period for both weight $\left(\mathrm{SGR}_{\mathrm{W}}\right)$ and length $\left(\mathrm{SGR}_{\mathrm{L}}\right)$ were significantly different among all groups, with $\mathrm{SGR}_{\mathrm{W}}$ in $\mathrm{T}$ salmon greater than eightfold higher than in $\mathrm{C}$ salmon and fourfold higher than R salmon (Fig. 1C and D; See Supplementary data, Table S1). Samples for the IMB microarray analysis were from a 2nd year class of fish, which were treated and grew in a similar fashion; however, growth rates were not specifically calculated.

\section{Effects of GH transgenesis on global liver gene expression with and without rationing}

Coho salmon transcripts responding reproducibly (as defined in Materials and methods) to GH transgenesis with and without feed rationing are reported in Tables S3-S16 (See Supplementary data at http://jme. endocrinology-journals.org/content/vol37/issue2/). 
Minimum microarray feature signal requirements (see Supplementary data, Table footnotes) were imposed to prevent inclusion of false positives in candidate informative gene lists due to random variation close to background levels. Changes in transcription levels, and degrees of similarity between salmonid cDNA ESTs and their top (most negative E-value) BLASTX or BLASTN hits against GenBank nr. or nt databases, are shown to identify candidate informative transcripts (See Supplementary data, Tables S3-S16). Informative unknown transcripts (cDNAs with no significant BLAST hits) are also reported. Informative transcripts in Tables S3-S14 (See Supplementary data) are listed by descending signal values in the appropriate channel (e.g. $\mathrm{T}$ for upregulated in Trelative to $\mathrm{C}$, or $\mathrm{C}$ for downregulated in $\mathrm{T}$ relative to $\mathrm{C}$ ) of one representative slide in the study. This allows rapid assessment of relative expression level, with highly abundant transcripts towards the top of the list and rare transcripts towards the bottom. For the purposes of intra- and interplatform comparisons, informative salmonid features (or spots) having significant BLAST hits with the same gene name are called by that name. These transcripts may represent identical salmon genes, orthologous sequences (for GRASP microarrays, which are predominantly Atlantic salmon, but contain some rainbow trout sequences), or paralogous sequences.

Many of the microarray-identified hepatic transcripts responsive to $\mathrm{GH}$ transgenesis with and without rationing are involved in iron homeostasis, energy metabolism, mitochondrial function, cellular proliferation and stress, and innate immunity. We, therefore, present cross-platform microarray data relevant to these biological processes in Tables 1-5. In crossplatform comparisons, reproducibly informative (see Materials and methods) gene names and accession numbers from individual microarray studies were used to query the normalized data from other microarray studies (See Supplementary data, Tables S3-S17). In Tables 1-5, the reproducibly informative feature data are shown in regular font, and the cross-platform data are shown in italicized font. When cross-platform scans identified multiple same-named microarray features, data were taken from features with signal intensities above threshold and regulation (average fold change between samples and direction of change) most closely resembling that observed in the reproducibly informative platform. With a few exceptions, there is a good level of cross-platform confirmation of informative genes in Tables 1-5. For example, four genes in Table 1 (hepcidin, heme oxygenase, and hemoglobins $\alpha$ and $\beta$ ) receive cross-platform confirmation, while one gene (GABARAP) does not. In Table 2, data from four genes (phosphogluconate dehydrogenase, glycerol-3-phosphate dehydrogenase, prostaglandin D-synthase, and $\delta-6$ fatty acyl desaturase) were confirmed by cross-platform comparison. In some instances, features assigned the same gene name between microarray platforms (or even within a platform) may represent distinct but related genes. This could explain apparent disagreements between platforms (i.e. GABARAP in Table 1, and barrierto-autointegration factor in Table 5).

Reproducibly informative genes identified in these microarray studies were confirmed in the following additional ways. Within each microarray study, several genes received 'internal confirmation' by appearing multiple times in a given informative gene list. For example, the 16K GRASP $\mathrm{T}<\mathrm{C}$ transcript list contains five separate microarray features identified as nuclear protein p8 (See Supplementary data, Table S9). Crossplatform comparisons of informative transcript lists identify genes or closely related genes behaving in a similar fashion between studies (i.e. microarray features identified as 20ß-hydroxysteroid dehydrogenase B are found in the $\mathrm{T}>\mathrm{C}$ transcript lists from both the $3 \cdot 5 \mathrm{~K}$ GRASP and the 16K GRASP studies; Fig. 4A). Comparisons of informative gene lists within and between microarray studies allow identification of suites of genes with the following inferred causes of dysregulation (followed by criteria for inclusion in the suites): genes induced by transgenesis (gene name must appear in at least one $\mathrm{T}>\mathrm{C}$ list and at least one $\mathrm{R}>\mathrm{C}$ list, so Tand $\mathrm{R}>$ $\mathrm{C}$ ); genes suppressed by transgenesis (gene name must appear in at least one $\mathrm{T}<\mathrm{C}$ list and at least one $\mathrm{R}<\mathrm{Clist}$, so $\mathrm{T}$ and $\mathrm{R}<\mathrm{C}$ ); genes indirectly induced by growth (gene name must appear in at least one $\mathrm{T}>\mathrm{C}$ list and at least one $\mathrm{R}<\mathrm{T}$ list, so $\mathrm{T}>\mathrm{C}$ and $\mathrm{R}$ ); genes indirectly suppressed by growth (gene name must appear in at least one $\mathrm{T}<\mathrm{C}$ list and at least one $\mathrm{R}>\mathrm{T}$ list, so $\mathrm{T}<\mathrm{C}$ and $\mathrm{R}$ ); genes induced by ration restriction (gene name must appear in at least one $\mathrm{R}>\mathrm{C}$ list and at least one $\mathrm{R}>\mathrm{T}$ list, so $\mathrm{R}>\mathrm{C}$ and $\mathrm{T}$ ); and genes suppressed by ration restriction (gene name must appear in at least one $\mathrm{R}<\mathrm{C}$ list and at least one $\mathrm{R}<\mathrm{T}$ list, so $\mathrm{R}<\mathrm{C}$ and T; Fig. 4B).

The data from reproducibly informative transcripts identified by each microarray study are compiled in Tables S3-S16 (See Supplementary data), and the overlap between these gene lists is shown in Fig. 4. It is important to note that the mean fold change and s.E.M. values presented in Tables S3-S16 (See Supplementary data) pertain to technical replicates (i.e. data from replicate microarrays comparing gene expression in pooled samples), while statistics associated with QPCR experiments (See Supplementary data, Tables S18-S23) pertain to data from biological replicates.

\section{3. $5 K$ GRASP $T<C$}

In the $3 \cdot 5 \mathrm{~K}$ GRASP $\mathrm{T}$ versus $\mathrm{C}$ study on fish from year class 1 (Fig. 2A), 28 microarray features representing 26 different transcripts were reproducibly greater than 
Table 1 Informative genes with functions related to iron homeostasis

\section{Function $^{\text {b }}$}

Gene name ${ }^{a}$

Hepcidin antibacterial peptide

$\mathrm{GABA}_{\mathrm{A}}$ receptor associated

protein (GABARAP)

Hemoglobin $\alpha$ chain

Hemoglobin $\beta$ chain

Kruppel-like globin gene activator

Heme oxygenase

Iron-sulfur cluster assembly U2 (ISCU2)
Regulation

Mean fold change in study ${ }^{c}$

\begin{tabular}{|c|c|c|c|}
\hline & $3.5 \mathrm{~K}$ GRASP & 16K GRASP & $4 \mathrm{~K} \mathrm{IMB}$ \\
\hline $\mathrm{T}<\mathrm{C}$ & $4 \cdot 63$ & $2 \cdot 15$ & NA \\
\hline $\mathrm{R}<\mathrm{C}$ & $2 \cdot 34$ & 2.03 & $\mathrm{LQ}$ \\
\hline $\mathrm{T}>\mathrm{C}$ & $2 \cdot 34$ & 0.80 & $\mathrm{NA}$ \\
\hline $\mathrm{R}<\mathrm{C}$ & $2 \cdot 23$ & $1 \cdot 11$ & LQ \\
\hline $\mathrm{R}<\mathrm{T}$ & $4 \cdot 18$ & 0.91 & NA \\
\hline $\mathrm{T}>\mathrm{C}$ & $1 \cdot 59$ & $2 \cdot 28$ & NA \\
\hline $\mathrm{R}>\mathrm{C}$ & $2 \cdot 64$ & $2 \cdot 20$ & 1.91 \\
\hline $\mathrm{T}>\mathrm{C}$ & $2 \cdot 14$ & $2 \cdot 36$ & NA \\
\hline$R>C$ & $3 \cdot 23$ & $1 \cdot 65$ & $1 \cdot 88$ \\
\hline $\mathrm{T}>\mathrm{C}$ & $\mathrm{NP}$ & $2 \cdot 33$ & NA \\
\hline $\mathrm{R}<\mathrm{C}$ & NP & $1 \cdot 31$ & $1 \cdot 82$ \\
\hline $\mathrm{T}<\mathrm{C}$ & $3 \cdot 21$ & LQ & NA \\
\hline
\end{tabular}

C, control non-transgenic; T, full-ration $\mathrm{GH}$ transgenic; $\mathrm{R}$, ration-fed $\mathrm{GH}$ transgenic.

${ }^{\mathrm{a}}$ For expressed sequence tags (ESTs) corresponding to informative microarray features, the gene names of the most significant (lowest $E$-value) BLASTX hits are shown.

${ }^{\mathrm{b}}$ Function associated with the EST's top BLAST hit or a functionally annotated putative ortholog, from Swiss-Prot (http://us.expasy.org/sprot/) or references discussed in this report.

'Number of replicate microarrays in 3.5K GRASP study: 3; in 16K GRASP study: 2; in 4K IMB study: 4. 'T <C'-fold change values are presented as C/T ratios, ' $T>C$ ' as $T / C$ ratios, ' $R<C$ ' as $C / R$ ratios, ' $R>C$ ' as $R / C$ ratios, ' $R<T$ ' as $T / R$ ratios, and ' $R>T$ ' as $R / T$ ratios. Entries in regular font were reproducibly informative (see Materials and methods). Complete lists of reproducibly informative features, including EST accession numbers, BLAST results (accession numbers, species affiliations, and $E$-values of top BLAST hits), Gene Ontology (GO) and other functional annotations, and fold change values, are available online in Supplementary data (http://jme.endocrinology-journals.org/content/vol37/issue2) Tables S3-S8 (3.5K GRASP study), Tables S9-S14 (16K GRASP study), and Tables

S15-S16 (4K IMB study). Entries in bold font correspond to genes appearing multiple times in an informative gene list; data from a single feature are shown, and additional feature data are available online in Supplementary data. Entries in italics were not present in reproducibly informative gene lists; selection criteria for these entries are presented in Results, and supporting data are available online in Supplementary data Table S17. NP, not present on microarray; NA, not applicable; as only the R versus C comparison was made using the IMB microarray (see Fig. 2). LQ, low quality signal data (signal intensities fell below threshold; see Supplementary data Table S17).

Table 2 Informative genes with functions related to energy metabolism

Function

\section{Gene name}

Glutamic-pyruvic transaminase

Transaldolase

Phosphogluconate dehydrogenase

Transketolase

3-Phosphoglycerate

dehydrogenase

Glycerol-3-phosphate

dehydrogenase

Prostaglandin D-synthase

$\delta-6$ fatty acyl desaturase

Fatty acid amide hydrolase

Fructose-1,6-bis phosphatase
Regulation

Mean fold change

3.5K GRASP

16K GRASP

Cellular nitrogen metabolism, gluconeogenesis $\mathrm{T}<\mathrm{C}$ Carbohydrate metabolism, pentose phosphate $R<C$ pathway (PPP)

Pentose-phosphate shunt, oxidative branch $\quad R<T$

Regulation of growth, PPP $\quad \mathrm{T}<\mathrm{C}$

$\mathrm{R}<\mathrm{C}$

Utilizes substrate from glycolysis to synthesize $R>C$ serine and glycine

Carbohydrate metabolism, gluconeogenesis

$R>T$

$\mathrm{T}>\mathrm{C}$

$\mathrm{R}>\mathrm{C}$

Prostaglandin metabolism, transporter activity $\mathrm{T}>\mathrm{C}$

$\mathrm{R}>\mathrm{C}$

Involved in bioconversion of linolenic acid to $\quad \mathrm{T}>\mathrm{C}$ eicosapentaenoic acid (EPA) $\quad R<T$ Terminates the signaling functions of bioactive $T<C$ fatty acid amides

Carbohydrate metabolism, gluconeogenesis $\quad \mathrm{T}<\mathrm{C}$

\subsection{K GRASP}

$2 \cdot 23$

$2 \cdot 14$

LQ

LQ

$4 \cdot 49 \quad 2 \cdot 38$

LQ $\quad 3.39$

LQ $\quad 3.54$

$8 \cdot 22$

$10 \cdot 37$

$2 \cdot 72$

$2 \cdot 50$

$4 \cdot 13$

$3 \cdot 17$

$2 \cdot 58$

$3 \cdot 64$

4. 04

NP
LQ

LQ

$2 \cdot 39$

$1 \cdot 87$

3. 83

$1 \cdot 52$

1.44

$1 \cdot 90$

LQ

$2 \cdot 41$

All column constructions and abbreviations are as described in Table 1 footnotes. Entries in regular, bold, or italicized font: see Table 1 footnotes. For supporting information, see Tables S3-S17 in Supplementary data at http://jme.endocrinology-journals.org/content/vol37/issue2/. 
Table 3 Informative genes involved in the mitochondrial electron transport chain

\section{Function}

Gene name

Cytochrome $c$ oxidase polypeptide VIII (COX8A)

Cytochrome $c$ oxidase subunit $\mathrm{VIb}$ isoform 1 (COX6B)

Cytochrome $c$

Ubiquinol-cytochrome $c$ reductase complex $11 \mathrm{kDa}$ protein

Ubiquinol-cytochrome $c$ reductase complex core protein 2

\begin{tabular}{|c|c|c|c|}
\hline & & $3.5 \mathrm{~K}$ GRASP & 16K GRASP \\
\hline $\begin{array}{l}\text { Nuclear-coded polypeptide chain of } \\
\text { cytochrome oxidase (terminal oxidase in } \\
\text { mitochondrial electron transport) }\end{array}$ & $\mathrm{T}>\mathrm{C}$ & $2 \cdot 97$ & NP \\
\hline $\begin{array}{l}\text { Connects the two COX monomers into the } \\
\text { physiological dimeric form }\end{array}$ & $\mathrm{T}>\mathrm{C}$ & $3 \cdot 79$ & NP \\
\hline $\begin{array}{l}\text { Electron carrier protein in the mitochondrial } \\
\text { matrix }\end{array}$ & $\begin{array}{l}T>C \\
R>C\end{array}$ & $\begin{array}{l}4 \cdot 48 \\
3 \cdot 60\end{array}$ & $\begin{array}{l}\mathrm{LQ} \\
\mathrm{LQ}\end{array}$ \\
\hline $\begin{array}{l}\text { Part of mitochondrial respiratory chain; may } \\
\text { mediate formation of complex between } \\
\text { cytochrome } c \text { and } c 1\end{array}$ & $\mathrm{~T}>\mathrm{C}$ & $2 \cdot 11$ & $1 \cdot 57$ \\
\hline $\begin{array}{l}\text { Part of mitochondrial respiratory chain; } \\
\text { required for assembly of the cytochrome } b-c 1 \\
\text { complex }\end{array}$ & $\mathrm{T}>\mathrm{C}$ & $3 \cdot 40$ & $1 \cdot 69$ \\
\hline
\end{tabular}

All column constructions and abbreviations are as described in Table 1 footnotes. Entries in regular, bold, or italicized font: see Table 1 footnotes. For supporting information, see Supplementary data, Tables S3-S17 (http://jme.endocrinology-journals.org/content/vol37/issue2).

twofold downregulated in $\mathrm{T}$ liver samples relative to $\mathrm{C}$ liver samples (See Supplementary data, Tables S3a and S3b; 'a' tables show mean fold change values for a nonredundant set of informative transcripts as well as the presence of same-named genes in other informative gene lists, and ' $b$ ' tables show data for each reproducibly informative feature from each contributing microarray). The most abundant downregulated transcript in $\mathrm{T}$ samples relative to $\mathrm{C}$ samples was alcohol dehydrogenase. Different microarray features with identical top BLAST hits in an informative gene list represent single genes or closely related paralogs.
For example, there are two CCAAT/enhancer-binding protein delta microarray features and two iron-sulfur cluster assembly U2 (ISCU2) microarray features in Table S3 (see Supplementary data at http://jme. endocrinology-journals.org/content/vol37/issue2). The presence of multiple entries of genes in an informative gene list provides internal validation of microarray results. From 3.5K GRASP microarray data, transcripts most highly suppressed $(>4 \cdot 5$-fold) in $\mathrm{T}$ relative to $\mathrm{C}$ liver were alcohol dehydrogenase $(8 \cdot 2$-fold $)$, metalloproteinase inhibitor $2(8 \cdot 2$-fold $)$, differentially regulated trout protein $1(6 \cdot 1$-fold $)$, and hepcidin

Table 4 Informative genes with functions related to cellular proliferation and stress

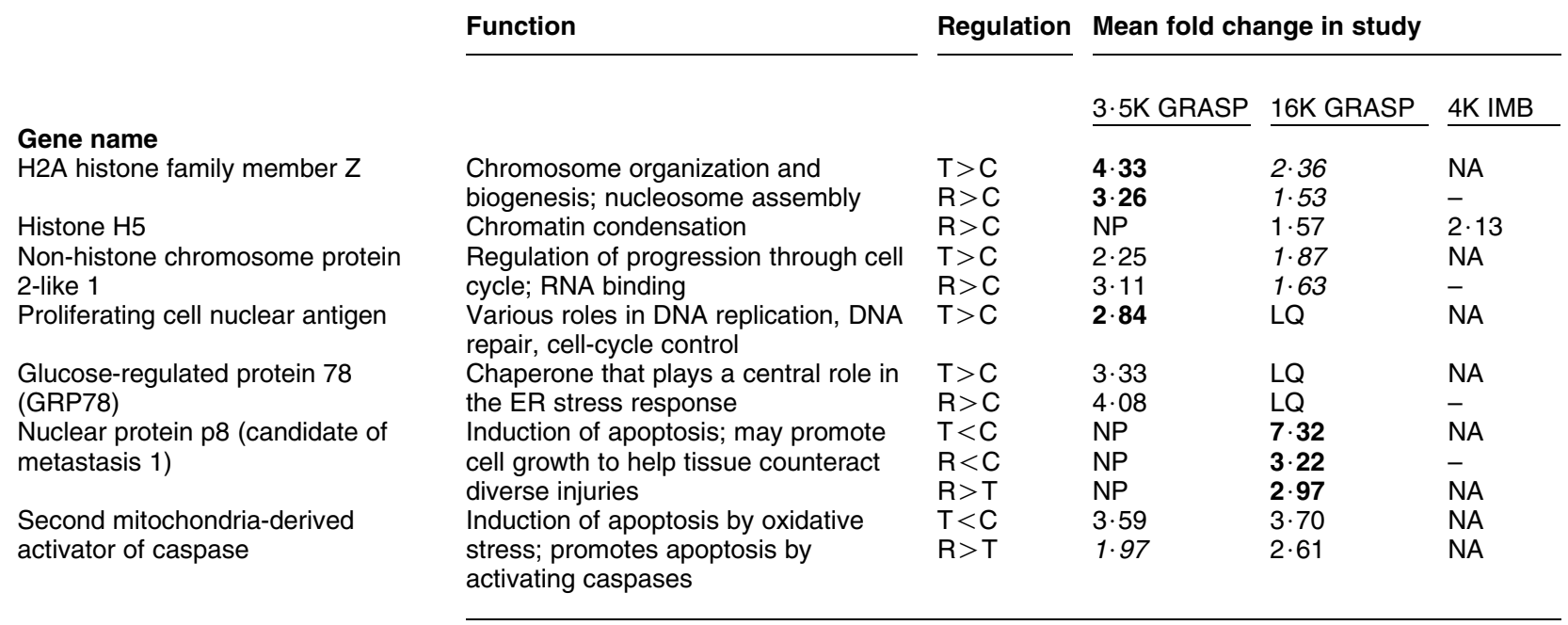

All column constructions and abbreviations are as described in Table 1 footnotes. Entries in regular, bold, or italicized font: see Table 1 footnotes. Dashes indicate genes were not confirmed due to low intensities, non-significance using SAM (see Materials and methods), or absence of the spot. For supporting information, see Supplementary data, Tables S3-S17 (http://jme.endocrinology-journals.org/content/vol37/issue2). 
Table 5 Immune-relevant informative genes

\section{Function}

Gene name
C-type lectin

Tachylectin

Complement component C3-3

Complement C3-4

Complement component C4

Complement component 7

Precerebellin-like protein

Differentially regulated trout protein 1

CCAAT/enhancer-binding protein $\delta$

Immunoglobulin $\mathrm{H}$ chain variable region

Thymus-specific serine peptidase

Serum albumin-related protein

Liver expressed antimicrobial peptide

2 isoform $B$

Barrier-to-autointegration factor

Regulation

Mean fold change in study

\begin{tabular}{|c|c|c|c|c|}
\hline & & $3 \cdot 5 \mathrm{~K}$ GRASP & 16K GRASP & $4 \mathrm{~K}$ IMB \\
\hline \multirow{3}{*}{$\begin{array}{l}\text { Agglutinates microorganisms in vivo; } \\
\text { sugar binding }\end{array}$} & $\mathrm{T}>\mathrm{C}$ & $N P^{a}$ & $8 \cdot 93$ & NA \\
\hline & $\mathrm{R}>\mathrm{C}$ & $N P^{a}$ & $2 \cdot 36$ & $2 \cdot 60$ \\
\hline & $\mathrm{R}<\mathrm{T}$ & $N P^{a}$ & $6 \cdot 20$ & NA \\
\hline Innate immunity; cell adhesion & $\mathrm{R}<\mathrm{C}$ & NP & NP & $1 \cdot 89$ \\
\hline $\begin{array}{l}\text { Complement activation; inflammatory } \\
\text { response }\end{array}$ & $\mathrm{R}<\mathrm{C}$ & $N P^{b}$ & $2 \cdot 20$ & $1 \cdot 80$ \\
\hline Endopeptidase inhibitor activity & $\mathrm{R}<\mathrm{C}$ & NP & NP & $1 \cdot 82$ \\
\hline $\begin{array}{l}\text { Complement activation; inflammatory } \\
\text { response }\end{array}$ & $\mathrm{T}<\mathrm{C}$ & LQ & $2 \cdot 74$ & NA \\
\hline \multirow[t]{2}{*}{ Response to pathogenic bacteria } & $\mathrm{T}<\mathrm{C}$ & $3 \cdot 33$ & LQ & NA \\
\hline & $\mathrm{R}<\mathrm{T}$ & $2 \cdot 69$ & LQ & NA \\
\hline Acute phase response (Gerwick et al. & $\mathrm{T}<\mathrm{C}$ & $1 \cdot 73$ & $5 \cdot 27$ & NA \\
\hline 2000); immune-relevant gene (Bayne & $\mathrm{R}<\mathrm{C}$ & $1 \cdot 33$ & $2 \cdot 12$ & $2 \cdot 26$ \\
\hline et al. 2001) & $\mathrm{R}>\mathrm{T}$ & 0.80 & $6 \cdot 82$ & NA \\
\hline Immune/acute phase gene (Bayne & $\mathrm{T}<\mathrm{C}$ & $6 \cdot 14$ & $3 \cdot 38$ & NA \\
\hline et al. 2001) & $\mathrm{R}<\mathrm{C}$ & $4 \cdot 61$ & $2 \cdot 66$ & $-^{\star}$ \\
\hline $\begin{array}{l}\text { Regulation of genes involved in } \\
\text { immune/inflammatory responses }\end{array}$ & $\mathrm{T}<\mathrm{C}$ & $2 \cdot 53$ & LQ & NA \\
\hline $\begin{array}{l}\text { Antibody component (humoral } \\
\text { immunity) }\end{array}$ & $\mathrm{R}>\mathrm{T}$ & $4 \cdot 35$ & LQ & NA \\
\hline $\begin{array}{l}\text { Protease that may play a role in T-cell } \\
\text { development }\end{array}$ & $\mathrm{R}>\mathrm{T}$ & $2 \cdot 49$ & LQ & NA \\
\hline $\begin{array}{l}\text { Immune/acute phase gene (Bayne } \\
\text { et al. 2001) }\end{array}$ & $\mathrm{T}<\mathrm{C}$ & NP & $2 \cdot 45$ & NA \\
\hline Defense response to bacteria & $\mathrm{R}>\mathrm{C}$ & NP & NP & $2 \cdot 97$ \\
\hline Response to virus & $\mathrm{R}>\mathrm{C}$ & $1 \cdot 02$ & LQ & $2 \cdot 58$ \\
\hline
\end{tabular}

All column constructions and abbreviations are as described in Table 1 footnotes. Entries in regular, bold, or italicized font, and dashes: see Table 1 footnotes. For supporting data, see Tables S3-S17 (see Supplementary data at http://jme.endocrinology-journals.org/content/vol37/issue2).

${ }^{\text {a }}$ The C-type lectin genes informative in the 16K GRASP and 4K IMB microarray experiments are most similar to newt (Pleurodeles walt) and nematode (Caenorhabditis elegans) lectin genes respectively see Tables S10, S12, S13, and S16 (see Supplementary data at http://jme.endocrinology-journals.org/ content/vol37/issue2), and are not found on the 3.5K GRASP microarray. The C-type lectin genes on the 3.5K GRASP microarray are most similar to rainbow trout (Oncorhynchus mykiss) C-type lectin 2-1 and C-type lectin 2-2.

${ }^{\mathrm{b}}$ The complement C3-like genes informative in the 16K GRASP and 4K IMB experiments are most similar to O. mykiss C3-3 and C3-4, and are not found on the 3.5K GRASP microarray. The C3-like genes on the 3.5K GRASP microarray are most similar to O. mykiss complement component C3-1. Asterisk: the IMB microarray study found a gene identified as differentially regulated trout protein 1 to be significantly $\mathrm{R}>\mathrm{C}$.

antibacterial peptide (4.6-fold). QPCR validation of microarray results using tissue samples from individual fish of year class 1 showed a $2 \cdot 3$-fold suppression of ISCU2 (s.E.m. $0 \cdot 2$ ) and a 3.2-fold suppression of hepcidin antibacterial peptide (S.E.M. 0.5 ) in T relative to $\mathrm{C}$ liver samples (Fig. 3A and B; See Supplementary data, Tables S18-S20 and S23). QPCR with fish from year class 1 also showed that ISCU2 was $2 \cdot 2$-fold suppressed (s.E.M. $0 \cdot 2$ ) in $\mathrm{R}$ relative to $\mathrm{C}$ samples (Fig. 3A; See Supplementary data, Tables S19 and S23).

\section{$16 K$ GRASP $T<C$}

In the 16K GRASP $\mathrm{T}$ versus $\mathrm{C}$ study on fish from year class 1 (Fig. 2B), 28 microarray features representing 20 different transcripts were reproducibly greater than twofold downregulated in $\mathrm{T}$ liver relative to $\mathrm{C}$ liver (See Supplementary data, Table S9a and S9b). The most abundant downregulated transcript in Tsamples relative to $\mathrm{C}$ samples was an unknown EST (GenBank nt accession number CA038313). There are five nuclear protein $\mathrm{p} 8$, three differentially regulated trout protein 1 , and three fatty acid-binding protein microarray features in Table S9 (See Supplementary data). From 16K GRASP microarray data, transcripts most highly suppressed ( $>4 \cdot 4$-fold) in T relative to $\mathrm{C}$ liver were nuclear protein p8 (7-3-fold), precerebellin-like protein (5-3-fold), alcohol dehydrogenase $(4 \cdot 7$-fold $)$, and fatty acid-binding protein $(4 \cdot 5$-fold).

\section{Overlap of $T<C$ from studies 1 and 2 (Fig. $2 A$ and $B$ )}

Four genes (alcohol dehydrogenase, differentially regulated trout protein 1 , second mitochondria-derived activator of caspase protein, and hepcidin antibacterial peptide) were greater than twofold suppressed in 


\section{A Cross-platform confirmation of informative genes}

\begin{tabular}{|c|c|c|c|c|c|c|c|c|c|c|}
\hline \multicolumn{2}{|c|}{ Microarray platform: } & \multicolumn{4}{|c|}{ 3.5K GRASP } & & \multicolumn{3}{|c|}{ 16K GRASP } & IMB \\
\hline
\end{tabular}

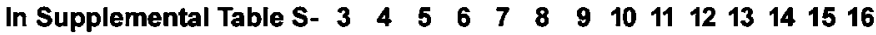

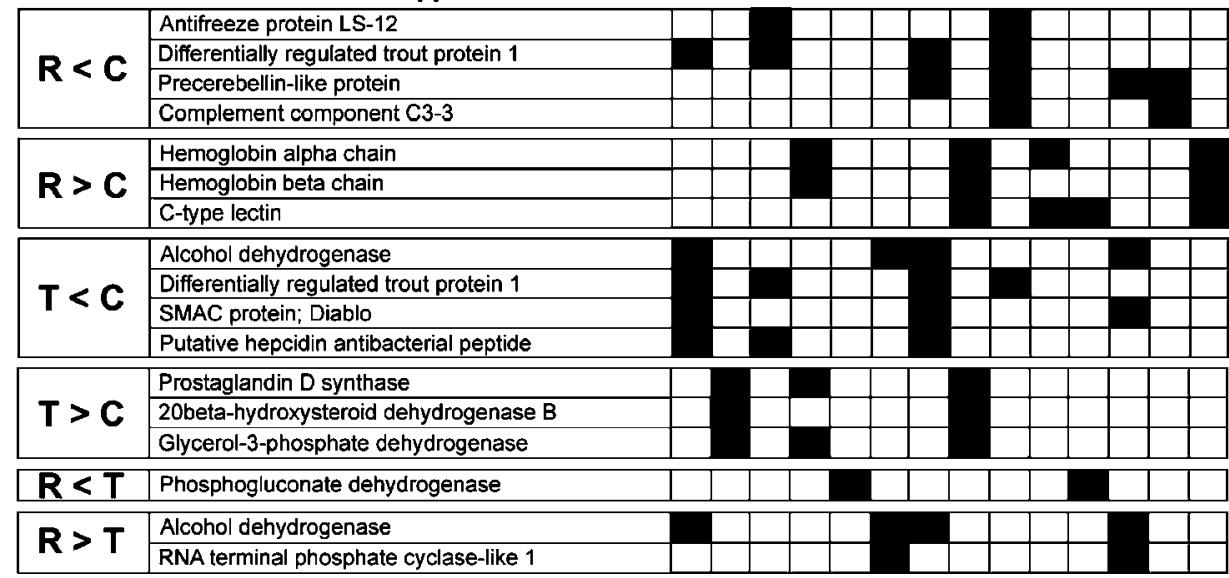

\section{B Summary of inferred causes of altered gene expression}

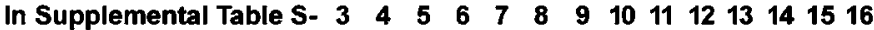

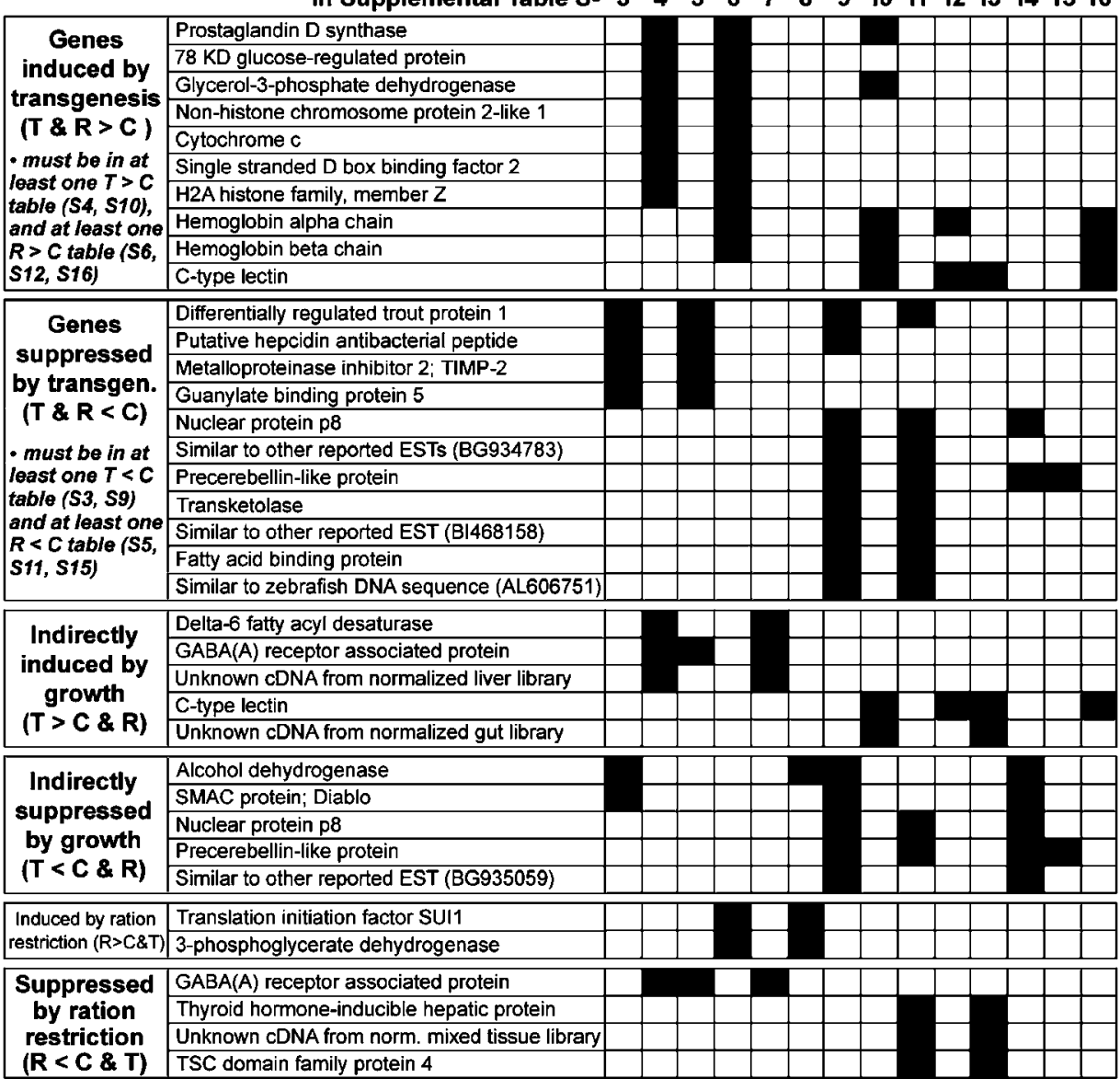


$\mathrm{T}$ relative to $\mathrm{C}$ in both the $3.5 \mathrm{~K}$ and $16 \mathrm{~K}$ GRASP microarray studies (Fig. 4A).

\section{3. $5 K$ GRASP $T>C$}

In the $3 \cdot 5 \mathrm{~K}$ GRASP $\mathrm{T}$ versus $\mathrm{C}$ study on fish from year class 1 (Fig. 2A), 36 microarray features representing 27 different transcripts were reproducibly greater than twofold upregulated in $\mathrm{T}$ liver relative to $\mathrm{C}$ liver (See Supplementary data, Tables S4a and S4b). The most abundant upregulated transcript in $\mathrm{T}$ relative to $\mathrm{C}$ liver was retinoid-binding protein 7 . There are five prostaglandin D-synthase, three cytochrome $c$, three proliferating cell nuclear antigen (PCNA), and two H2A histone family member Z microarray features in Table S4 (See Supplementary data). From 3.5K GRASP microarray data, transcripts most highly induced $(>4 \cdot 1$-fold) in $\mathrm{T}$ relative to $\mathrm{C}$ liver were cytochrome $c(4 \cdot 5$-fold $)$, replication factor C 4 (4.5-fold), H2A histone family member Z (4.3-fold), and prostaglandin D-synthase (4-2-fold). Since there was a high level of redundancy (providing internal validation) in this informative gene list, transcripts of interest for QPCR validation were selected from informative gene lists with less redundancy.

\section{K GRASP T>C}

In the 16K GRASP T versus C study on fish from year class 1 (Fig. 2B), 31 microarray features representing 18 different transcripts were reproducibly greater than twofold upregulated in $\mathrm{T}$ liver relative to $\mathrm{C}$ liver (See Supplementary data, Tables S10a and S10b). The most abundant upregulated transcript in Tsamples relative to C samples was ubiquitin carboxy-terminal hydrolase L1. There are two C-type lectin, seven $\beta$ hemoglobin, two $\alpha$ hemoglobin, and six prostaglandin D-synthase microarray features in Table S10 (See Supplementary data). From 16K GRASP microarray data, transcripts most highly induced $(>3 \cdot 7$-fold) in T relative to $\mathrm{C}$ liver were C-type lectin (8.9-fold) and prostaglandin D-synthase $(3 \cdot 8$-fold $)$.

\section{Overlap of $T>C$ from studies 1 and 2 (Fig. $2 A$ and $B$ )}

Three genes (prostaglandin D-synthase, 20ß-hydroxysteroid dehydrogenase $\mathrm{B}$, and glycerol-3-phosphate dehydrogenase) were greater than twofold induced in
T relative to $\mathrm{C}$ in both the $3.5 \mathrm{~K}$ and $16 \mathrm{~K}$ GRASP studies (Fig. 4A).

\section{3. $5 K$ GRASP $R<C$}

In the $3 \cdot 5 \mathrm{~K}$ GRASP $\mathrm{R}$ versus $\mathrm{C}$ study on fish from year class 1 (Fig. 2A), ten microarray features representing ten different transcripts were reproducibly greater than twofold downregulated in $\mathrm{R}$ liver relative to $\mathrm{C}$ liver (See Supplementary data, Tables S5a and S5b). The most abundant downregulated transcript in $\mathrm{R}$ relative to $\mathrm{C}$ liver was related to antifreeze protein LS-12 and is probably an apolipoprotein. From $3 \cdot 5 \mathrm{~K}$ GRASP microarray data the transcripts most highly suppressed $(>3 \cdot 2-$ fold) in $\mathrm{R}$ relative to $\mathrm{C}$ liver were differentially regulated trout protein 1 (4·6-fold), cysteine protease CP14 (3·6fold), guanylate-binding protein 5 (3-4-fold), and antifreeze protein LS-12 (3·3-fold). From this informative transcript list, hepcidin antibacterial peptide and transaldolase 1 were selected for QPCR validation, because their functions relate to immunity and carbohydrate metabolism respectively. QPCR validation of microarray results using tissue samples from individual fish of year class 1 showed a $2 \cdot 8$-fold suppression of hepcidin antibacterial peptide (S.E.M. $0 \cdot 2$ ) and a $2 \cdot 3$-fold suppression of transaldolase 1 (s.E.M. $0 \cdot 2$ ) in $\mathrm{R}$ relative to C liver samples (Fig. 3B and C; See Supplementary data, Tables S18, S20, S21, and S23). QPCR with year class 1 liver template samples and transaldolase 1 primers also showed 1.5 -fold higher expression in $\mathrm{T}$ relative to $\mathrm{C}$ samples (s.E.M. $0 \cdot 2$ ), and 3 1 -fold higher expression in $\mathrm{T}$ relative to R samples (s.e.m. 0.3; Fig. 3C; See Supplementary data, Tables S21 and S23).

\section{K GRASP $R<C$}

In the 16K GRASP $\mathrm{R}$ versus $\mathrm{C}$ study on fish from year class 1 (Fig. 2B), 20 microarray features representing 16 different transcripts were reproducibly greater than twofold downregulated in $\mathrm{R}$ liver relative to $\mathrm{C}$ liver (See Supplementary data, Tables S11a and S11b). The most abundant downregulated transcript in $\mathrm{R}$ samples relative to $\mathrm{C}$ samples was thyroid hormone-inducible hepatic protein. There are three antifreeze protein LS12 , two nuclear protein $\mathrm{p} 8$, and two fatty acid-binding protein microarray features in Table S11 (See Supplementary data online). From 16K GRASP microarray data, transcripts most highly suppressed $(>3 \cdot 1$-fold $)$ in $\mathrm{R}$ relative to $\mathrm{C}$ liver were antifreeze protein LS-12

Figure 4 Intra- and interplatform comparisons of reproducibly informative genes from microarray studies, compiled from Tables S3-S16 (see Supplementary data at http://jme.endocrinology-journals.org/content/vol37/issue2). (A) Cross-platform comparisons of informative transcript lists. To be included, a gene name had to be present in a particular informative transcript list (e.g. upregulated in $\mathrm{R}$ relative to $\mathrm{C}$, or $\mathrm{R}>\mathrm{C}$ ) in studies using at least two different microarray platforms. Black boxes indicate the presence of gene names in tables in this report. (B) Overlap of informative gene lists within and between microarray studies infers causes of altered gene expression. C, control nontransgenic; $\mathrm{R}$, ration-fed $\mathrm{GH}$ transgenic; $\mathrm{T}$, full ration $\mathrm{GH}$ transgenic. 
(3.9-fold), thyroid hormone-inducible hepatic protein $(3 \cdot 7$-fold $)$, transketolase $(3 \cdot 5$-fold $)$, and nuclear protein $\mathrm{p} 8(3 \cdot 2$-fold $)$.

\section{$4 K I M B R<C$}

In the IMB $\mathrm{R}$ versus $\mathrm{C}$ study on fish from year class 2 (Fig. 2C), the reproducibly downregulated transcripts in $\mathrm{R}$ liver relative to $\mathrm{C}$ liver encoded precerebellin-like protein, tachylectin, heme oxygenase, two complement C3 components, and four unknown products (See Supplementary data, Tables S15a and S15b).

\section{Overlap of $R<C$ between microarray studies}

Two genes (antifreeze protein LS-12 and differentially regulated trout protein 1) were greater than twofold suppressed in $\mathrm{R}$ relative to $\mathrm{C}$ in both the $3.5 \mathrm{~K}$ and $16 \mathrm{~K}$ GRASP microarray studies (Fig. 4A). Two other genes (precerebellin-like protein and complement C3-3) were present in the $\mathrm{R}<\mathrm{C}$ gene lists of both the 16K GRASP and the $4 \mathrm{~K}$ IMB studies (Fig. 4A). Interestingly, the IMB microarray study found that differentially regulated trout protein 1 was upregulated in $\mathrm{R}$ relative to $\mathrm{C}$ and this was found to be significant using SAM analysis (see Materials and methods). None of the remainder of the downregulated transcripts uncovered using the $3 \cdot 5 \mathrm{~K}$ GRASP microarray was confirmed using the IMB microarray, either because the intensities fell below threshold (e.g. hepcidin, $\mathrm{GABA}_{\mathrm{A}}$ receptor associated protein), because SAM analysis did not find them to be statistically significant (transaldolase, amoebocyte aggregation factor, antifreeze protein LS-12), or because they were not present on the IMB microarray (metalloproteinase inhibitor 2, retinoid $\mathrm{X}$ receptor $\alpha$, guanylate-binding protein 5, cysteine protease CP14). Using the IMB microarray with year class 2 fish samples, antifreeze protein LS-12 homolog was significantly downregulated in $\mathrm{R}$ relative to $\mathrm{C}$ head kidney, but not in liver (data not shown).

\section{5K GRASP R>C}

In the $3 \cdot 5 \mathrm{~K}$ GRASP $\mathrm{R}$ versus $\mathrm{C}$ study on fish from year class 1 (Fig. 2A), 22 microarray features representing 17 different transcripts were reproducibly greater than twofold upregulated in $\mathrm{R}$ liver relative to $\mathrm{C}$ liver (See Supplementary data, Tables S6a and S6b). The most abundant and fourth-most abundant upregulated transcripts in $\mathrm{R}$ relative to $\mathrm{C}$ liver were the $\alpha$ and $\beta$ chains of hemoglobin respectively. There are three prostaglandin D-synthase, three cytochrome $c$, and two H2A histone family member Z microarray features in Table S6 (See Supplementary data online). From $3 \cdot 5 \mathrm{~K}$ GRASP microarray data, transcripts most highly induced $(>3 \cdot 5$-fold $)$ in $\mathrm{R}$ relative to $\mathrm{C}$ liver were 3-phosphoglycerate dehydrogenase (8.2-fold), $78 \mathrm{kDa}$ glucose-regulated protein $(4 \cdot 1$-fold $)$, nucleolar protein NOP5 $(3 \cdot 8$-fold $)$, and cytochrome $c(3 \cdot 6$-fold $)$. Due to the high level of internal validation within this informative gene list, transcripts of interest for QPCR validation were selected from informative gene lists with less redundancy.

\section{K GRASP $R>C$}

In the 16K GRASP R versus $\mathrm{C}$ study on fish from year class 1 (Fig. 2B), three microarray features representing three different transcripts were reproducibly greater than twofold induced in $\mathrm{R}$ liver relative to $\mathrm{C}$ liver (See Supplementary data, Tables S12a and S12b). The most abundant upregulated transcript in $\mathrm{R}$ samples relative to $\mathrm{C}$ samples was hemoglobin $\alpha$. From 16K GRASP microarray data, transcripts reproducibly induced in $\mathrm{R}$ relative to $\mathrm{C}$ liver were hemoglobin $\alpha$ (2·2-fold), C-type lectin (2.4-fold), and phospholipid hydroperoxide glutathione peroxidase $(2 \cdot 3$-fold $)$.

\section{$4 K I M B R>C$}

In the IMB $\mathrm{R}$ versus $\mathrm{C}$ study on fish from year class 2 (Fig. 2C), the reproducibly upregulated transcripts in $\mathrm{R}$ relative to $\mathrm{C}$ samples encoded liver-expressed antimicrobial peptide 2, C-type lectin, barrier-to-autointegration factor (also called breakpoint cluster protein), histone $\mathrm{H} 5$, a novel protein containing a ChaC-like domain, hemoglobins $\alpha$ and $\beta$, and two unknown products (See Supplementary data, Tables S16a and S16b). There are two barrier-to-autointegration factor microarray features in Table S16. One additional feature in this informative gene list came from a clone (BG935738) containing two inserts, one for hemoglobin $\alpha$ and the other for monocyte chemoattractant protein-1 (See Supplementary data, Table S16b). Given the positive result from another spot containing hemoglobin $\alpha$, the signal from BG935738 likely arises from hemoglobin $\alpha$; however, there may also be a contribution from monocyte chemoattractant protein. Again, several of the transcripts identified using the $3.5 \mathrm{~K}$ GRASP microarray were not confirmed using the IMB microarray due to low intensities, non-significance using SAM, or absence of the spot.

\section{Overlap of $R>C$ between microarray studies}

Hemoglobin $\alpha$ chain was greater than twofold induced in $\mathrm{R}$ relative to $\mathrm{C}$ in all three microarray studies (Fig. 4A). Hemoglobin $\beta$ chain was present in the $\mathrm{R}>$ $\mathrm{C}$ gene lists of both the $3.5 \mathrm{~K}$ GRASP and the $4 \mathrm{~K} \mathrm{IMB}$ studies, and C-type lectin was present in the $\mathrm{R}>\mathrm{C}$ gene lists of both the 16K GRASP and the $4 \mathrm{~K}$ IMB studies (Fig. 4A). 


\section{3. $5 K$ GRASP $R<T$}

In the $3 \cdot 5 \mathrm{~K}$ GRASP $\mathrm{T}$ versus $\mathrm{R}$ study on fish from year class 1 (Fig. 2A), 11 microarray features representing 11 different transcripts had greater than twofold lower expression in $\mathrm{R}$ relative to $\mathrm{T}$ liver in all three slides (See Supplementary data, Tables S7a and S7b). The most abundant transcript in this list was protein disulfide isomerase related. From $3 \cdot 5 \mathrm{~K}$ GRASP microarray data, transcripts with the highest $\mathrm{T} / \mathrm{R}$ fold differences $(>$ 3.4-fold) were an unknown (6.3-fold), phosphogluconate dehydrogenase $(4 \cdot 5$-fold $), \mathrm{GABA}_{\mathrm{A}}$ receptor associated protein $(4 \cdot 2$-fold $)$, kinesin-like protein $2(3 \cdot 7$ fold), $\delta$ - 6 fatty acyl desaturase $(3 \cdot 6$-fold), and apoptosis inhibitor survivin 1 (3-5-fold). The unknown, GABA $_{A}$ receptor associated protein, and $\delta-6$ fatty acyl desaturase microarray features in this informative transcript list are also present in Table S4 (See Supplementary data online) (3.5K GRASP T $>\mathrm{C}$; Fig. $4 \mathrm{~B})$, suggesting that these genes are induced in $T$ relative to $R$ rather than suppressed in $R$ relative to T. QPCR validation of microarray results, using templates from fish of year class 1 and primers for phosphogluconate dehydrogenase, showed a 4-2-fold T/R difference (s.E.M. 0 -2; Fig. 3D; See Supplementary data, Tables S18, S22, and S23). QPCR with year class 1 templates also showed that phosphogluconate dehydrogenase was $1 \cdot 7$-fold induced in Trelative to $\mathrm{C}$ (s.E.M. $0 \cdot 1$ ), and $2 \cdot 8$-fold suppressed in $\mathrm{R}$ relative to $\mathrm{C}$ (s.E.M. 0·3; Fig. 3D; See Supplementary data, Tables S22 and S23).

\section{K GRASP $R<T$}

In the 16K GRASP $\mathrm{T}$ versus $\mathrm{R}$ study on fish from year class 1 (Fig. 2B), eight microarray features representing seven different transcripts had greater than twofold lower expression in $\mathrm{R}$ liver relative to $\mathrm{T}$ liver in both slides (See Supplementary data, Tables S13a and S13b). The most abundant transcript in this list is C-type lectin, and there are two C-type lectin features in Table S13 (See Supplementary data online). From 16K GRASP microarray data, transcripts with the highest $\mathrm{T} / \mathrm{R}$ fold differences $(>4 \cdot 0$-fold) were C-type lectin $(6 \cdot 2$-fold $)$, an unknown (EST accession number CA038900; 5.9fold), and TSC domain family protein 4 ( $4 \cdot 1$-fold).

\section{Overlap of $R<T$ from studies 1 and 2 (Fig. $2 A$ and B)}

One gene, phosphogluconate dehydrogenase, was greater than twofold induced in $\mathrm{T}$ relative to $\mathrm{R}$ liver in both the $3.5 \mathrm{~K}$ and 16K GRASP studies (Fig. 4A).

\section{3. $5 K$ GRASP R>T}

In the $3 \cdot 5 \mathrm{~K}$ GRASP $\mathrm{T}$ versus $\mathrm{R}$ study on fish from year class 1 (Fig. 2A), nine microarray features representing nine different transcripts had greater than twofold higher expression in $\mathrm{R}$ relative to $\mathrm{T}$ liver in all three slides (See Supplementary data, Tables S8a and S8b). The most abundant transcript in this list was alcohol dehydrogenase. From 3.5K GRASP microarray data, transcripts with the highest $\mathrm{R} / \mathrm{T}$ fold differences $(>$ $3 \cdot 8$-fold) were 3-phosphoglycerate dehydrogenase (10 4 -fold), immunoglobulin $\mathrm{H}$ chain variable region (4·3-fold), and alcohol dehydrogenase (3.9-fold). Since 3-phosphoglycerate dehydrogenase and translation initiation factor SUI1 are also found in Table S6 (See Supplementary data online) (3.5K GRASP R $>$ C; Fig. 4B), these genes are likely induced in $\mathrm{R}$ relative to $\mathrm{T}$ rather than suppressed in T relative to $R$.

\section{K GRASP R>T}

In the 16K GRASP T versus R study on fish from year class 1 (Fig. 2B), 11 microarray features representing ten different transcripts reproducibly had greater than twofold higher expression in $\mathrm{R}$ relative to $\mathrm{T}$ liver (See Supplementary data, Tables S14a and S14b). The most abundant transcript in this list was precerebellin-like protein. There are two nuclear protein $\mathrm{p} 8$ microarray features in Table S14 (See Supplementary data online). From 16K GRASP microarray data, transcripts with the highest $\mathrm{R} / \mathrm{T}$ fold differences $(>2 \cdot 8$-fold) were precerebellin-like protein $(6 \cdot 8$-fold $)$, nuclear protein p8 $(3 \cdot 0$ fold), and alcohol dehydrogenase (2.9-fold).

\section{Overlap of $R>T$ from studies 1 and 2 (Fig. $2 A$ and B)}

Two genes, RNA terminal phosphate cyclase-like 1 and alcohol dehydrogenase, had greater than twofold higher expression in $\mathrm{R}$ relative to $\mathrm{T}$ liver in both the $3.5 \mathrm{~K}$ and the 16K GRASP studies (Fig. 4A). Since alcohol dehydrogenase is also present in the $\mathrm{T}<\mathrm{C}$ gene lists from both the $3 \cdot 5 \mathrm{~K}$ GRASP study (See Supplementary data, Table S3) and the 16K GRASP study (See Supplementary data, Table S9; Fig. 4A and B), this gene is likely suppressed in $T$ relative to $R$ rather than induced in $\mathrm{R}$ relative to $\mathrm{T}$.

\section{Discussion}

We used three different salmonid cDNA microarray platforms $(3 \cdot 5 \mathrm{~K}$ GRASP, 16K GRASP, and 4K IMB) to study the impact of GH transgenesis with and without ration restriction on global gene expression in hepatic tissues from pre-reproductive (smolt) coho salmon. DNA microarrays have been used to identify GH-responsive genes in adult mammalian liver (Thompson et al. 2000, Flores-Morales et al. 2001, Olsson et al. 2003, Ahluwalia et al. 2004). Here, we report the first use of cDNA microarrays to study the influence of GH transgenesis on liver gene expression in a non-mammalian vertebrate, 
and the first such study using sexually immature animals. The use of multiple microarray platforms, each containing a partial salmonid transcriptome, increased the overall proportion of the transcriptome considered in the present studies. Some sequences are lost during the process of cDNA microarray fabrication, largely due to unsuccessful amplification (Rise et al. 2004b). An advantage of a multiple platform approach is that clones lost in the fabrication of one platform may be represented in another.

The functional annotations of informative salmonid liver transcripts responding to $\mathrm{GH}$ transgenesis with and without food rationing point to molecular pathways altered under these different genotypic and nutritional conditions. A large number of salmonid genes identified in these studies are involved in iron homeostasis, mitochondrial function, carbohydrate metabolism, apoptosis, cellular proliferation, and innate immunity. The discussion is, therefore, focused primarily on these biological processes, with particular attention paid to genes (or gene names) with expression profiles that were confirmed within and/or across platforms, and informative transcripts with growth-relevant functional annotations.

\section{Iron homeostasis and signal transduction}

\section{GABARAP, hepcidin, and hepatic transcription factors}

In the $3 \cdot 5 \mathrm{~K}$ GRASP study, $\mathrm{GABA}_{\mathrm{A}}$ receptor associated protein (GABARAP) was upregulated in $\mathrm{T}$ relative to $\mathrm{C}$ and $T$ relative to $\mathrm{R}$ liver, and downregulated in $\mathrm{R}$ relative to $\mathrm{C}$ liver (Table 1; $\mathrm{T}>\mathrm{C}>\mathrm{R}$ ). Thus, in this study, GABARAP was found to be both indirectly induced by growth ( $\mathrm{T}>\mathrm{C}$ and $\mathrm{R}$ ) and suppressed by ration restriction ( $\mathrm{R}<\mathrm{C}$ and $\mathrm{T}$; Fig. $4 \mathrm{~B})$. A transcript identified as GABARAP was not informative in the 16K GRASP study (Table 1), and potential causes of such apparent disagreement between platforms were previously presented. GABARAP is extremely highly conserved in the metazoa, with amino acid identity values ranging from 93 to $98 \%$ in such organisms as fruit fly (Drosophila melanogaster), amphioxus (Branchiostoma belcheri tsingtaunese), and zebrafish (Danio rerio). Human GABARAP, first identified by a yeast two-hybrid system using parts of the $\mathrm{GABA}_{\mathrm{A}}$ receptor as bait, bears significant amino acid sequence similarity to light chain-3 of microtubuleassociated proteins (MAPs) 1A and 1B (Wang et al. 1999). GABARAP is ubiquitously expressed, suggesting that it has likely generalized or multiple functions in addition to its putative role in moving, sorting, and clustering $\mathrm{GABA}_{\mathrm{A}}$ receptors (Wang et al. 1999, Kneussel \& Betz 2000, Stangler et al. 2002). GABARAP binds transferrin receptor (TfR) and potentially plays a role in trafficking or cycling of TfR (Green et al. 2002). Liver TfR plays a key role in iron metabolism, delivering iron-bound transferrin to the endosomal compartment and stimulating hepatocytes to release hepcidin (Green et al. 2002, Sharma et al. 2005). In addition to GABARAP, other genes involved in iron homeostasis (e.g. hepcidin and heme oxygenase) were also dysregulated in the $\mathrm{GH}$ transgenic coho salmon experiments giving rise to this report.

Microarray (3.5K and 16K GRASP) and QPCR data on tissues from fish of year class 1 (Fig. 2A and B) indicated that a coho salmon transcript encoding a putative polypeptide related to the acute phase protein hepcidin was downregulated in both $\mathrm{T}$ and $\mathrm{R}$ relative to $\mathrm{C}$ liver (Table 1; Figs 3B and 4A and B). Hepcidin was 1 of 11 genes found to be suppressed by GH transgenesis ( $T$ and $\mathrm{R}<\mathrm{C}$; Fig. 4B). Mammalian hepcidin (or liver-expressed antimicrobial peptide-1) genes are expressed primarily in liver, and hepcidin is believed to be among the most abundant transcripts in adult mammalian liver (Pigeon et al. 2001, Courselaud et al. 2002). Similarly, coho salmon hepcidin was the fourth-most abundant transcript in the 3.5K GRASP $\mathrm{T}<\mathrm{C}$ list (See Table S3 at http://jme. endocrinology-journals.org/content/vol37/issue2), and the third-most abundant transcript in both the $3.5 \mathrm{~K}$ GRASP R $<$ C list (See Table S5 in Supplementary data) and the 16K GRASP $\mathrm{T}<\mathrm{C}$ list (See Supplementary data, Table S9).

Hepcidin is thought to play an important role in vertebrate innate immune responses to microbial challenge (Shike et al. 2004, Lauth et al. 2005). Mammalian hepcidin proteins exhibit antibacterial and antifungal activity (Krause et al. 2000, Park et al. 2001). Hepcidin expression is upregulated in human (Nemeth et al. 2003) and mouse (Pigeon et al. 2001) hepatocytes exposed to lipopolysaccharide, and also in Atlantic salmon (Douglas et al. 2003), zebrafish (Shike et al. 2004), and striped bass (Lauth et al. 2005) liver tissues in response to bacterial infections. In addition to its conserved function in innate immunity, hepcidin also serves as a modulator of iron homeostasis (Courselaud et al. 2002, Lee et al. 2005). Hepcidin expression in mammalian liver is strongly induced by iron excess (Pigeon et al. 2001), and strongly suppressed by anemia and hypoxia (Nicolas et al. 2002). Therefore, the suppressed hepcidin expression observed in GH transgenic coho salmon liver regardless of nutritional status suggests that these fish should have compromised innate immunity, as well as altered iron homeostasis, specifically increased iron availability for hemoglobin biosynthesis. Challenge studies have indicated that the strain of GH transgenic salmon used in the present study do indeed have reduced resistance to bacterial infections (Jhingan et al. 2003). Hemoglobin $\alpha$ and $\beta$ are two of the ten genes found to be induced by GH transgenesis ( $\mathrm{T}$ and $\mathrm{R}>\mathrm{C}$; Fig. $4 \mathrm{~B}$ ). The induction of these hemoglobin genes in $\mathrm{GH}$ transgenic liver was confirmed using all three 
microarray platforms (Table 1). Increased expression of hemoglobin genes in $\mathrm{R}$ and $\mathrm{T}$ relative to $\mathrm{C}$ liver tissues indicates a need for additional hemoglobin in the transgenic fish, perhaps due to the higher metabolic rate required for enhanced growth. Increased hemoglobin levels would also result from the increased activation of hemoglobin promoters by upregulated Kruppel-like globin gene activator, and the decreased degradation of existing hemoglobin by downregulated heme oxygenase (Table 1). Furthermore, it is possible that GH transgenic liver may be more vascularized than control liver, resulting in increased numbers of erythrocytes and thus increased levels of hemoglobin transcripts. Analyses of cDNA sequences upstream of mammalian (Pigeon et al. 2001) and bass (Shike et al. 2002) hepcidin transcriptional start sites identified putative-binding sites for the transcription factors $\mathrm{C} / \mathrm{EBP} \beta$, hepatocyte nuclear factor (HNF), and nuclear factor- $\kappa \mathrm{B}$. Interestingly, the $3 \cdot 5 \mathrm{~K}$ GRASP study found that hepcidin, $\mathrm{C} / \mathrm{EBP} \delta$, HNF-3 $\beta$, and inhibitor of nuclear factor $\kappa \mathrm{B} \alpha(\mathrm{I} \kappa \mathrm{B} \alpha)$ were all reproducibly greater than twofold suppressed in $\mathrm{T}$ liver relative to $\mathrm{C}$ liver (See Supplementary data, Table S3). Using microarray experiments on aortic RNA samples of $\mathrm{Hx}$ rats treated with saline or $\mathrm{GH}$, Tivesten et al. (2004) found that I $\mathrm{I} \mathrm{B} \alpha$ was $54 \%$ downregulated by GH. We saw a 3·6-fold downregulation of coho salmon $\mathrm{I} \kappa \mathrm{B} \alpha$ in $\mathrm{T}$ liver relative to $\mathrm{C}$ liver (See Supplementary data, Table S3).

The $3 \cdot 5 \mathrm{~K}$ GRASP study found that a coho salmon transcript similar to the Forkhead box/winged helix (Fox) transcription factor HNF-3 $\beta$ (Foxa2) was suppressed in T relative to $\mathrm{C}$ liver (See Supplementary data, Table S3). HNF-3 $\beta$ has not been identified previously in salmonids, and this EST displays amino acid identity values ranging from 81 to $85 \%$ with orthologs from zebrafish (Danio rerio), Mozambique tilapia (Oreochromis mossambicus), and Japanese medaka (Oryzias latipes). HNF-3 $\beta$ orthologs serve various roles in vertebrate embryogenesis (Nishizaki et al. 2001, Suri et al. 2004), and mammalian Fox transcription factors expressed in liver play important roles in growth control (Foucher et al. 2002). The $\mathrm{GH} /$ insulin-like growth factor-I (IGF-I) system plays a key role in mammalian postnatal growth (Lupu et al. 2001). GH stimulates the liver to secrete IGF-I, which mediates GH functions (Liu \& LeRoith 1999). Transgenic mice overexpressing HNF-3 $\beta$ in hepatocytes exhibited dramatic postnatal growth retardation, likely due to upregulation of insulin-like growth factor-binding protein (IGFBP)-1, which could sequester functional IGF-I (Rausa et al. 2000). Conversely, suppressed HNF-3 $\beta$ expression in T liver could lower levels of circulating IGFBP, and enhance growth by increasing IGF-I bioavailability.

\section{Iron-sulfur cluster assembly protein}

A transcript with $79 \%$ amino acid similarity to ironsulfur cluster assembly U2 (IscU2) from human was suppressed in $\mathrm{T}$ and $\mathrm{R}$ relative to $\mathrm{C}$ liver in fish of year class 1 (Table 1; Fig. 3A). IscU genes encode highly conserved proteins that bind iron and participate in iron-sulfur ( $\mathrm{Fe}-\mathrm{S})$ cluster biosynthesis in prokaryotic and eukaryotic cells (Hwang et al. 1996, Zheng et al. 1998). Eukaryotic Fe-S proteins (requiring Fe-S clusters for function) are found in the mitochondria, cytosol, and nucleus (Gerber et al. 2004), and perform important roles in several cellular processes including electron transport, catalysis, DNA repair, and regulation of gene expression (Ramelot et al. 2004). In mammals, most $\mathrm{Fe}-\mathrm{S}$ proteins are located in the mitochondria (Tong \& Rouault 2000). Humans have two IscU splice variants: IscU1 localizes to the cytosol, and IscU2 localizes to the mitochondria (Tong \& Rouault 2000). While it is known that yeast IscU mutations cause iron overload in mitochondria (Garland et al. 1999, Schilke et al. 1999), the precise role played by IscU proteins in iron homeostasis is unknown (Tong \& Rouault 2000). The downregulation of IscU2 in GH transgenic coho salmon liver could result in decreased levels of intracellular free iron, potentially leading to the formation of free radicals or increased levels of extracellular free iron that would be available for hemoglobin biosynthesis.

\section{Energy metabolism}

GH transgenic coho salmon have enhanced feed intake and specific growth rates (Devlin et al. 2004a,b) indicating that their metabolic machinery must be able to handle the increased flux of energy and nutrients through different pathways. Initially, at the organ level, this is achieved at least in part by enhancement of gut surface area (Stevens \& Devlin $2000,2005)$ to allow increased uptake of nutrients. GH is known to be a hormone that affects metabolism of carbohydrates, lipids, and protein in vertebrates (Higgs et al. 1975, Harvey et al. 1995, Fauconneau et al. 1996, Cook et al. 2000a,b), and consequently it is reasonable to anticipate changes in the levels of enzymes involved in these processes in growth-accelerated GH transgenic salmon. Remarkably, relatively few changes in the expression of genes encoding these enzymes have been detected.

\section{Carbohydrate metabolism}

The 16K GRASP microarray contains genes for all 11 enzymes involved in glycolysis, five of six genes for enzymes in the TCA cycle, and three of six enzymes involved in glycogen and galactose metabolism. Yet, 
among these genes, none was found to change greater than twofold in expression level on any of the three microarray sets nor among any treatment groups, suggesting that if carbohydrate metabolism is being altered (with the exception of the pentose phosphate pathway (PPP) - see below), this is being accomplished primarily by mechanisms other than those that influence transcript abundance.

\section{The PPP}

Genes encoding three enzymes in the PPP, transaldolase, phosphogluconate dehydrogenase, and transketolase, were dysregulated in GH transgenic liver samples (Table 2; Figs $3 \mathrm{C}$ and $\mathrm{D}$ and $4 \mathrm{~A}$ and $\mathrm{B}$ ). The PPP consists of two branches: a non-oxidative branch with reversible reactions, and an oxidative branch with irreversible reactions. Transaldolase is thought to be the rate-limiting enzyme in the non-oxidative branch (Puskas et al. 2000, Grossmann et al. 2004), which contains several reactions catalyzed by transketolase. Phosphogluconate dehydrogenase is in the oxidative branch, which has glucose 6-phosphate dehydrogenase as the rate-limiting enzyme (Puskas et al. 2000). The two branches of the PPP are functionally connected, contributing to the generation of $\mathrm{NADPH}$ and thereby supplying reducing power needed for cell growth and proliferation (Barroso et al. 1998, Puskas et al. 2000). NADPH is also required for synthesis of reduced glutathione (GSH), which protects cells from the damaging effects of reactive oxygen intermediates (Banki et al. 1996). The PPP is, therefore, an important component of cellular defense against oxidative stress (Grossmann et al. 2004). The PPP also plays an important role in the production of D-ribose, a key component required for nucleic acid biosynthesis during growth.

Microarray and QPCR data on tissues from fish of year class 1 showed that both transaldolase and phosphogluconate dehydrogenase were downregulated in $\mathrm{R}$ and upregulated in Trelative to $\mathrm{C}$ ( or $\mathrm{T}>\mathrm{C}>\mathrm{R}$, the same gene expression profile as GABARAP; Fig. 3C and D). Phosphogluconate dehydrogenase was in the $\mathrm{R}<\mathrm{T}$ gene lists of both the $3.5 \mathrm{~K}$ and the 16K GRASP studies (Table 2; Fig. 4A). Collectively, the data show that transaldolase and phosphogluconate dehydrogenase were indirectly induced by growth $(\mathrm{T}>\mathrm{C}$ and $\mathrm{R})$ and also suppressed by ration restriction $(\mathrm{R}<\mathrm{C}$ and $\mathrm{T})$. The relatively low $\mathrm{T}$ versus $\mathrm{C}$ and $\mathrm{R}$ versus $\mathrm{C}$ fold differences (Fig. 3C and D), along with the stringent criteria for inclusion in the informative transcript lists arising from GRASP microarray studies (i.e. must be greater than twofold different in all slides of a study) likely contributed to the absence of transaldolase and phosphogluconate dehydrogenase in Fig. 4B. Transketolase is present in the $\mathrm{T}<\mathrm{C}$ and $\mathrm{R}<\mathrm{C}$ lists from the 16K GRASP study (Table 2 ), and it is, therefore, inferred that this gene is suppressed by GH transgenesis ( $T$ and $\mathrm{R}<\mathrm{C}$; Fig. $4 \mathrm{~B}$ ).
Enhanced growth in GH transgenic coho salmon is accompanied by hepatic gene expression profiles indicating increased mitochondrial activity, particularly in $\mathrm{T}$ fish (See Supplementary data at http://jme.endocrinologyjournals.org/content/vol37/issue2, Tables S4 and S6), which would result in increased levels of reactive oxygen intermediates. Cultured mammalian lymphocytes respond to treatment with the pro-oxidant dehydroascorbate with increased activities of PPP enzymes (transaldolase, glucose 6-phosphate dehydrogenase, and 6-phosphogluconate dehydrogenase), increased intracellular GSH, and increased resistance to apoptosis (Puskas et al. 2000). In a similar fashion, the induction of transaldolase and phosphogluconate dehydrogenase in T liver could stimulate the PPP to produce the additional NADPH needed to maintain adequate GSH to mitigate cellular damage caused by oxidative stress. However, reductions in transketolase activity as seen in T salmon may be a strategy to ensure that sufficient D-ribose is available for nucleic acid synthesis rather than shifting its conversion to glyceraldehyde-3-phosphate for glycolysis, a pathway which does not appear to be modulated in transgenic salmon (see above). The $3 \cdot 5 \mathrm{~K}$ GRASP study identified five different genes involved in mitochondrial electron transport as being induced in $\mathrm{T}$ liver relative to $\mathrm{C}$ liver compared with one induced mitochondrial gene in $\mathrm{R}$ relative to $\mathrm{C}$ (Table 3), suggesting that mitochondrial activity and levels of reactive oxygen intermediates would be higher in $\mathrm{T}$ than in R or C liver samples. Still, significantly increased growth rates in $\mathrm{R}$ relative to $\mathrm{C}$ fish (Fig. 1) and elevated cytochrome $c$ transcript levels in $\mathrm{R}$ relative to $\mathrm{C}$ liver (Table 3) suggest that $\mathrm{R}$ fish cells may experience increased oxidative stress relative to controls. Both branches of the PPP appear to be suppressed in $\mathrm{R}$ liver relative to $\mathrm{C}$ and $\mathrm{T}$ liver (Fig. 3C and D). Inhibition of the PPP in these fish could result in decreased NADPH and GSH levels, making $\mathrm{R}$ tissues more susceptible to oxidative injury. Interestingly, starvation causes decreased 6-phosphogluconate dehydrogenase activity in trout liver (Barroso et al. 1998), and decreased transaldolase activity in rat liver (Heinrich et al. 1976). We speculate that suppression of PPP genes in R liver may suggest that these fish were in a physiological state approaching starvation. Calorie-restriction in ration-fed GH transgenic coho salmon would likely have physiological consequences such as depressed immune function. The impact of rationing on the global gene expression and health of $\mathrm{GH}$ transgenic salmon warrants further investigation.

\section{Amino acid metabolism}

More than 20 genes encoding enzymes involved in amino acid metabolism are represented on the $16 \mathrm{~K}$ GRASP microarray. Glutamate-pyruvate transaminase, 
an enzyme involved in metabolism of amino groups collected from amino acids, was found to be moderately reduced in transgenic salmon, possibly to reduce catabolism of amino acids to ensure sufficient supplies are available to support protein synthesis. Another enzyme gene, 3-phosphoglycerate dehydrogenase, was found to be greater than eightfold stimulated in $\mathrm{R}$ salmon relative to $\mathrm{C}$ or $\mathrm{T}$ salmon. This enzyme utilizes a substrate from within the glycolysis pathway to synthesize two non-essential amino acids, serine and glycine. $\mathrm{R}$ salmon are provided with insufficient dietary energy relative to $\mathrm{T}$ and $\mathrm{C}$ salmon, and consequently enhanced synthesis of certain amino acids may be critical to maintain cellular functions.

\section{Lipid, cholesterol, and prostaglandin metabolism}

GH is well known to enhance lipid catabolism in many vertebrate systems, including fish (Higgs et al. 1975, Harvey et al. 1995). The microarray platforms used in the present study contain at least 14 genes involved in lipid and cholesterol metabolism. Among these, glycerol-3-phosphate dehydrogenase is induced in both $\mathrm{R}$ and $\mathrm{T}$ salmon, consistent with hormonal modulation of lipid metabolism. Prostaglandin D-synthase and $\delta-6$ fatty acyl desaturase were also induced in transgenic salmon, indicating that additional effects of lipid and prostaglandin metabolism are occurring in transgenic salmon. Fatty acid amide synthetase and hydrolase were both suppressed in transgenic salmon, suggesting modification of fatty acid amide signaling molecules. Of interest is the enhancement of the $\delta$ - 6 fatty acyl desaturase gene in T salmon relative to $\mathrm{C}$ and $\mathrm{R}$ salmon liver. This encodes activity important for bioconversion of linolenic acid $(18: 3 n-3)$ to eicosapentaenoic acid (EPA; 20:5n-3; Hastings et al. 2004). EPA is an important member of the family of omega-3 highly unsaturated fatty acids, which provide significant health benefits to humans consuming fish oil products.

\section{Mitochondrial function}

Whereas basal oxygen utilization rates in GH transgenic salmon are not enhanced, metabolic rates following feeding are significantly elevated due to enhanced specific dynamic action (Leggatt et al. 2003) suggesting that overall oxygen consumption and energy transport must be enhanced in GH transgenic salmon to meet the demands of accelerated growth. Several genes involved in mitochondrial electron transport (cytochrome $c$ oxidase polypeptides VIB and VIII, cytochrome $c$, ubiquinolcytochrome $c$ reductase hinge protein, and ubiquinolcytochrome $c$ reductase core protein 2) are induced in $\mathrm{T}$ relative to $\mathrm{C}$ liver (Table 3 ). Cytochrome $c$ is also present in the $3.5 \mathrm{~K}$ GRASP $\mathrm{R}>\mathrm{C}$ transcript list (See
Supplementary data at http://jme.endocrinology-journals.org/content/vol37/issue2, Table S6), and is therefore classified as a gene induced by $\mathrm{GH}$ transgenesis ( $\mathrm{T}$ and R>C C; Fig. 4B). Flores-Morales et al. (2001) found that cytochrome $b 5$ expression was suppressed in Hx rat livers relative to control rat livers, and induced in GH-treated $\mathrm{Hx}$ rat livers relative to untreated $\mathrm{Hx}$ rat livers. In addition, several other cytochrome genes were downregulated in $\mathrm{Hx}$ rat livers relative to normal livers (Flores-Morales et al. 2001). GH probably influences mitochondrial function in both mammalian and salmonid liver cells due to the increased metabolic demand.

\section{Cellular proliferation and stress response in GH transgenic liver}

Several genes dysregulated in GH transgenic coho salmon liver cells are involved in cell proliferation. Multiple microarray features identified as PCNA were greater than twofold upregulated in Trelative to $\mathrm{C}$ liver (Table 4; See Supplementary data at http://jme. endocrinology-journals.org/content/vol37/issue2, Table S4). PCNA plays various roles in DNA replication, DNA repair, chromatin remodeling, and cell-cycle control (Maga \& Hübscher 2003). Other genes involved in cell-cycle regulation (non-histone chromosome protein 2-like) and chromatin organization (histone H2A family member $\mathrm{Z}$ and histone H5) are also upregulated in GH transgenic liver (Table 4). Histone H2A family member $\mathrm{Z}$ has various functions in transcriptional regulation and maintenance of genomic stability (Farris et al. 2005). Therefore, its induction in growth-enhanced salmon liver may be a part of a mechanism by which GH transgenic cells control genomic fidelity in a hyper-proliferative state.

We observed gene expression changes co-occurring with $\mathrm{GH}$ transgenesis which indicate that the transgenic liver is under stress. The $3.5 \mathrm{~K}$ GRASP study identifies glucose-regulated protein 78 (GRP78) as being upregulated in Tand $\mathrm{R}$ liver relative to $\mathrm{C}$ liver (Table 4 ). It is, therefore, inferred that GRP78 is induced by GH transgenesis ( $\mathrm{T}$ and $\mathrm{R}>\mathrm{C}$; Fig. 4B). GRPs are endoplasmic reticulum stress-associated proteins that protect cells against damage during changing environmental conditions (Ko et al. 2002). GRP genes are induced by various stresses that disrupt endoplasmic reticulum (ER) function (Kaufman 1999). The GRP78 gene is induced in cultured chicken and mammalian cells deprived of glucose (Shiu et al. 1977, Lin \& Lee 1984) or exposed to calcium ionophores (Wu et al. 1981). GRP78 is a chaperone that plays a central role in the ER stress response. In the absence of ER stress, transducers of ER stress signaling (e.g. activating tanscription factor 6 (ATF6), proteinkinase-like ER kinase (PERK)) are kept inactive through interaction with GRP78 (Lee 2005). Conditions causing ER stress 
(e.g. glucose deprivation, pathological conditions, or accumulation of misfolded proteins in the ER) release ER stress transducers from GRP78, activating the apoptosis-inducing ER stress signaling (Lee 2005). GRP78 overexpression decreases the ER stress response, protecting stressed cells from apoptosis (Dorner et al. 1992, Kaufman 1999). GRP78 also protects ER-stressed cells from death by interfering with caspase activation (Lee 2005). The upregulation of GRP78 in GH transgenic coho salmon liver tissue suggests that the transgenic liver cells experience ER stress and that GRP78 confers cytoprotection by mitigating this stress.

A salmonid transcript similar to nuclear protein $\mathrm{p} 8$, a growth-relevant protein responsive to cellular stress and starvation (Malicet et al. 2003), was also found to be dysregulated in GH transgenic salmon liver relative to control samples. In the 16K GRASP study, p8 was downregulated in Trelative to $\mathrm{C}$ liver and $\mathrm{R}$ relative to $\mathrm{C}$ liver, and upregulated in $\mathrm{R}$ relative to $\mathrm{T}$ liver (Table 4; $\mathrm{C}>\mathrm{R}>\mathrm{T})$. Therefore, $\mathrm{p} 8$ is inferred to be both suppressed by $\mathrm{GH}$ transgenesis $(\mathrm{T}$ and $\mathrm{R}<\mathrm{C}$ ) and indirectly suppressed by growth ( $\mathrm{T}<\mathrm{C}$ and R; Fig. 4B). Nuclear protein $\mathrm{p} 8$ is involved in cell-cycle regulation, and has been reported to mediate both the inhibition of growth (Vasseur et al. 2002) and the promotion of growth (Vasseur et al. 1999) in different cell types. A microarray study identified Drosophila p8 as being induced by starvation, prompting speculation that $\mathrm{p} 8$ might be activated to stop cell growth when nutrients are scarce (Zinke et al. 2002). There may be similarities between fly and fish p8 functions, as we observed an inverse relationship between hepatic $\mathrm{p} 8$ expression and salmon growth rate (Fig. 1). A recent study using human pancreatic cancer cell lines demonstrated that activation of growth-promoting intracellular pathways (e.g. Raf $\rightarrow$ MAPK and ERK kinase (MEK) $\rightarrow$ extracellular signal-regulated kinase (ERK)) suppressed p8 expression, while activation of growth-inhibiting pathways (e.g. p38) upregulated p8 expression (Malicet et al. 2003). These findings point to pathways potentially altered in salmon as a result of GH transgenesis, and possible molecular mechanisms involved in enhanced growth in these fish.

\section{Immune-relevant genes affected by GH transgenesis}

In addition to hepcidin and prostaglandin D-synthase, several other immune-relevant salmon liver transcripts (e.g. C-type lectin superfamily members, complement components, and precerebellin-like) were potentially responsive to $\mathrm{GH}$ transgenesis with or without ration restriction (Table 5). Salmon transcripts encoding C-type lectins were found in $\mathrm{R}>\mathrm{C}$ transcript lists from the 16K GRASP study (See Supplementary data at http:// jme.endocrinology-journals.org/content/vol37/issue2,
Table S12) and the IMB study (See Supplementary data, Table S16; Fig. 4A). Since a C-type lectin was also present in the 16K GRASP T $>$ C list (See Supplementary data, Table S10) and R $<$ T list (See Supplementary data, Table S13), the expression of at least one gene in the C-type lectin superfamily appears to be $\mathrm{T}>\mathrm{R}>\mathrm{C}$. Based on their presence in multiple informative transcript lists across the GRASP and IMB studies, C-type lectins appear to be both induced by transgenesis ( $T$ and $\mathrm{R}>\mathrm{C}$ ) and indirectly induced by growth (T>C and R; Fig. 4B). C-type lectinlike transcripts, identified in subtractive cDNA libraries enriched for salmon hepatic genes induced by $A$. salmonicida infection, are thought to play a role in immunity or inflammation (Ewart et al. 2005). Other immune-relevant salmonid liver genes potentially responsive to $\mathrm{GH}$ transgenesis with or without ration restriction include complement components $\mathrm{C} 7(\mathrm{~T}<\mathrm{C}$ and $\mathrm{R}<\mathrm{T})$, C4 $(\mathrm{T}<\mathrm{C})$, and C3-3 and C3-4 $(\mathrm{R}<\mathrm{C})$, as well as tachylectin $(\mathrm{R}<\mathrm{C})$, and precerebellin-like $(\mathrm{T}<\mathrm{C}$ and $\mathrm{R}<\mathrm{C}$; Table 5). The upregulation of C-type lectin, and downregulation of several other acute phase reactants in $\mathrm{R}$ and Tsamples, suggest that $\mathrm{GH}$ transgenic coho salmon may have altered innate immune function, consistent with studies showing that this strain has reduced resistance to bacterial infections (Jhingan et al. 2003).

\section{GH signaling}

Several of the components of the signaling pathway by which GH mediates its effects on gene expression (Moutoussamy et al. 1998) are present on the GRASP microarrays and provided strong enough signals to yield reliable assessments of expression, although most differed by less than twofold between transgenic and control samples and thus did not meet the criteria used to identify differentially expressed genes as described above. For example, $\mathrm{GH}$ receptor was induced in $\mathrm{T}$ and $\mathrm{R}$ samples (1.15-and $1 \cdot 73$-fold respectively) relative to $\mathrm{C}$, consistent with the known stimulatory effect of $\mathrm{GH}$ on its own receptor's transcription in $\mathrm{GH}$ transgenic mice (Orian et al. 1991). Protein kinase $\mathrm{C}$, which plays a regulatory role in mediating GH effects on cellular processes (Moutoussamy et al. 1998), was found to be induced by more than twofold in transgenic salmon on the $3.5 \mathrm{~K}$ GRASP microarray (see tables S6a and S6b in Supplemental data at http://jme.endocrinology-journals.org/content/ vol37/issue2). A transcript with similarity to rainbow trout signal transducer and activator of transcription (STAT)-1 appeared to be reduced in both fully fed and rationrestricted transgenic salmon to an average of 0.53 of the level found in controls. Similarly, mitogen-activated protein kinase (MAPK) (which can be activated by the cytoplasmic domain of the $\mathrm{GH}$ receptor) is also reduced in $\mathrm{GH}$ transgenic salmon relative to controls (to $0 \cdot 51$ in fully fed and to $0 \cdot 83$ in ration-restricted transgenics). 
Thus, some effects on signaling pathway components beyond the GH receptor appear to be in directions which would lead to reduction of $\mathrm{GH}$ signaling strength, which may indicate the presence of feedback mechanisms, which are operating to attenuate signaling and from chronic overexpression of this hormone (e.g. see Miquet et al. 2004). For example, one target of GH signaling, IGFI, was not found to be induced in any of the transgenic samples examined (range $0 \cdot 61-1 \cdot 02$-fold). However, in general, effects on signal transduction pathways appear to be quite subtle, indicating that regulation may arise from the cumulative effects of many small changes, rather than large effects on any one regulatory component.

\section{Acknowledgements}

This research was supported by the Shaw Foundation (MLR), the Canadian Biotechnology Strategy Genomics Fund (RHD), and Genome Canada, Genome BC, the Province of BC, the National Research Council (NRC) and the Natural Sciences and Engineering Research Council of Canada (BFK). This is NRC publication number 42610.

We would like to thank Tom Hansen for assisting in submission of microarray data to Gene Expression Omnibus. The authors declare that there is no conflict of interest that would prejudice the impartiality of this scientific work.

\section{References}

Ahluwalia A, Clodfelter KH \& Waxman DJ 2004 Sexual dimorphism of rat liver gene expression: regulatory role of growth hormone revealed by deoxyribonucleic acid microarray analysis. Molecular Endocrinology 18 747-760.

Banki K, Hutter E, Colombo E, Gonchoroff NJ \& Perl A 1996 Glutathione levels and sensitivity to apoptosis are regulated by changes in transaldolase expression. Journal of Biological Chemistry 271 32994-33001.

Barroso JB, Peragón J, Contraras-Jurado C, García-Salguero L, Corpas FJ, Esteban FJ, Peinado MA, De La Higuera M \& Lupiáñez JA 1998 Impact of starvation-refeeding on kinetics and protein expression of trout liver NADPH-production systems. American Journal of Physiology 274 R1578-R1587.

Bayne CJ, Gerwick L, Fujika K, Nakao M \& Yano T 2001 Immune-relevant (including acute phase) genes identified in the livers of rainbow trout, Oncorhynchus mykiss, by means of suppression subtractive hybridization. Developmental and Comparative Immunology 25 205-217.

Brazma A, Hingamp P, Quackenbush J, Sherlock G, Spellman P, Stoeckert C, Aach J, Ansorge W, Ball CA, Causton HC et al. 2001 Minimum information about a microarray experiment (MIAME) toward standards for microarray data. Nature Genetics 29 365-371.

Cook JT, McNiven MA, Richardson GF \& Sutterlin AM 2000 $a$ Growth rate, body composition and feed digestibility/conversion of growthenhanced transgenic Atlantic salmon (Salmo salar). Aquaculture $\mathbf{1 8 8}$ $15-32$.

CookJT, Sutterlin AM \& McNiven MA $2000 b$ Effect of food deprivation on oxygen consumption and body composition of growth-enhanced transgenic Atlantic salmon (Salmo salar). Aquaculture 188 47-63.

Courselaud B, Pigeon C, Inoue Y, Inoue J, Gonzalez FJ, Leroyer P, Gilot D, Boudjema K, Guguen-Guillouzo C, Brissot P et al. 2002 C/EBP $\alpha$ regulates hepatic transcription of hepcidin, an antimicrobial peptide and regulator of iron metabolism. Journal of Biological Chemistry 277 41163-41170.

Davidson MB 1987 Effect of growth hormone on carbohydrate and lipid metabolism. Endocrine Reviews 8 115-131.

Devlin RH, Yesaki TY, Biagi CA, Donaldson EM, Swanson P \& Chan WK 1994 Extraordinary salmon growth. Nature 371 209-210.

Devlin RH, Biagi CA, Yesaki TY, Smailus DE \& Byatt JC 2001 Growth of domesticated transgenic fish. Nature 409 781-782.

Devlin RH, Biagi CA \& Yesaki TY 2004a Growth, viability and genetic characteristics of $\mathrm{GH}$ transgenic coho salmon strains. Aquaculture 236 607-632.

Devlin RH, D'Andrade M, Uh M \& Biagi CA $2004 b$ Population effects of growth hormone transgenic coho salmon depend on food availability and genotype by environment interactions. PNAS 101 9303-9308.

Dorner AJ, Wasley LC \& Kaufman RJ 1992 Overexpression of GRP78 mitigates stress induction of glucose regulated proteins and blocks secretion of selective proteins in Chinese hamster ovary cells. EMBO Journal 11 1563-1571.

Douglas SE, Gallant JW, Liebscher RS, Dacanay A \& Tsoi SCM 2003 Identification and expression analysis of hepcidin-like antimicrobial peptides in bony fish. Developmental and Comparative Immunology 27 589-601.

Ewart KV, Belanger J, Williams J, Karakach T, Richards RC, Tsoi SCM \& Douglas SE 2005 Identification of differentially expressed genes involved in Atlantic salmon (Salmo salar) host-pathogen interaction using microarray technology. Developmental and Comparative Immunology 29 333-347.

Farris SD, Rubio ED, Moon JJ, Gombert WM, Nelson BH \& Krumm A 2005 Transcription-induced chromatin remodeling at the c-myc gene involves the local exchange of histone H2A.Z. Journal of Biological Chemistry 280 25298-25303.

Fauconneau B, Mady MP \& LeBail PY 1996 Effect of growth hormone on muscle protein synthesis in rainbow trout (Oncorhynchus mykiss) and Atlantic salmon (Salmo salar). Fish Physiology and Biochemistry 15 $49-56$.

Flores-Morales A, Ståhlberg N, Tollet-Egnell P, Lundeberg J, Malek RL, Quackenbush J, Lee NH \& Norstedt G 2001 Microarray analysis of the in vivo effects of hypophysectomy and growth hormone treatment on gene expression in the rat. Endocrinology 142 3163-3176.

Foucher I, Volovitch M, Frain M, Kim JJ, Souberbielle JC, Gan L, Unterman TG, Prochiantz A \& Trembleau A 2002 Hoxa5 overexpression correlates with IGFBP1 up-regulation and postnatal dwarfism: evidence for an interaction between Hoxa5 and Forkhead box transcription factors. Development 129 4065-4074.

Garland SA, Hoff K, Vickery LE \& Culotta VC 1999 Saccharomyces cerevisiae ISU1 and ISU2: members of a well-conserved gene family for iron-sulfur cluster assembly. Journal of Molecular Biology 294 897-907.

Gerber J, Neumann K, Prohl C, Mühlenhoff U \& Lill R 2004 Yeast scaffold proteins Isulp and Isu2p are required inside mitochondria for maturation of cytosolic Fe/S proteins. Molecular and Cellular Biology 24 4848-4857.

Gerwick L, Reynolds WS \& Bayne CJ 2000 A precerebellin-like protein is part of the acute phase response in rainbow trout, Oncorhynchus mykiss. Developmental and Comparative Immunology 24 597-607.

Green F, O'Hare T, Blackwell A \& Enns CA 2002 Association of human transferrin receptor with GABARAP. FEBS Letters 518 101-106.

Grossmann CE, Qian Y, Banki K \& Perl A 2004 ZNF143 mediates basal and tissue-specific expression of human transaldolase. Journal of Biological Chemistry 279 12190-12205.

Harvey S, Sacnes CG, Daughaday WH 1995 Growth Hormone. Boca Raton, FL: CRC Press.

Hastings N, Agaba M, Tocher D, Zheng X, Dickson C, Dick J \& Teale A 2004 Molecular cloning and functional characterization of fatty acyl desaturase and elongase cDNAs involved in the production of eicosapentaenoic and docosahexaenoic acids from alpha-linolenic acid in Atlantic salmon (Salmo salar). Marine Biotechnology 6 463-474. 
Heinrich PC, Morris HP \& Weber G 1976 Behavior of transaldolase (EC 2.2.1.2) and transketolase (EC 2.2.1.1) activities in normal, neoplastic, differentiating, and regenerating liver. Cancer Research 36 3189-3197.

Higgs D, Donaldson E, Dye H \& McBride J 1975 A preliminary investigation of the effect of bovine growth hormone on growth and muscle composition of coho salmon (Oncorhynchus kisutch). General and Comparative Endocrinology 27 240-253.

Hwang DM, Dempsey A, Tan KT \& Liew CC 1996 A modular domain of NifU, a nitrogen fixation cluster protein, is highly conserved in evolution. Journal of Molecular Evolution 43 536-540.

Jhingan E, Devlin RH \& Iwama GK 2003 Disease resistance, stress response and effects of triploidy in growth hormone transgenic coho salmon. Journal of Fish Biology 63 806-823.

Kaufman RJ 1999 Stress signaling from the lumen of the endoplasmic reticulum: coordination of gene transcriptional and translational controls. Genes and Development 13 1211-1233.

Kneussel M \& Betz H 2000 Clustering of inhibitory neurotransmitter receptors at developing postsynaptic sites: the membrane activation model. Trends in Neurosciences 23 429-435.

Ko HS, Uehara T \& Nomura Y 2002 Role of ubiquitin associated with protein-disulfide isomerase in the endoplasmic reticulum in stressinduced apoptotic cell death. Journal of Biological Chemistry 277 35386-35392.

Krause A, Neitz S, Magert HJ, Schulz A, Forssmann WG, Schulz-Knappe P \& Adermann K 2000 LEAP-1, a novel highly disulfide-bonded human peptide, exhibits antimicrobial activity. FEBS Letters 480 147-150.

Lauth X, Babon JJ, Stannard JA, Singh S, Nizet V, Carlberg JM, Ostland VE, Pennington MW, Norton RS \& Westerman ME 2005 Bass hepcidin synthesis, solution structure, antimicrobial activities and synergism, and in vivo hepatic response to bacterial infections. Journal of Biological Chemistry 280 9272-9282.

Lee AS 2005 ER chaperone and signaling regulator GRP78/BiP as a monitor of endoplasmic reticulum stress. Methods 35 373-381.

Lee P, Peng H, Gelbart T, Wang L \& Beutler E 2005 Regulation of hepcidin transcription by interleukin-1 and interleukin-6. PNAS 102 1906-1910.

Leggatt RA, Devlin RH, Farrell AP \& Randall DJ 2003 Oxygen uptake of growth hormone transgenic coho salmon during starvation and feeding. Journal of Fish Biology 62 1053-1066.

Lin AY \& Lee AS 1984 Induction of two genes by glucose starvation in hamster fibroblasts. PNAS 81 988-992.

Liu JL \& LeRoith D 1999 Insulin-like growth factor I is essential for postnatal growth in response to growth hormone. Endocrinology 140 $5178-5184$

Lupu F, Terwilliger JD, Lee K, Segre GV \& Efstratiadis A 2001 Roles of growth hormone and insulin-like growth factor 1 in mouse postnatal growth. Developmental Biology 229 141-162.

Maga G \& Hübscher U 2003 Proliferating cell nuclear antigen (PCNA): a dancer with many partners. Journal of Cell Science 116 3051-3060.

Malicet C, Lesavre N, Vasseur S \& Iovanna JL 2003 p8 inhibits the growth of human pancreatic cancer cells and its expression is induced through pathways involved in growth inhibition and repressed by factors promoting cell growth. Molecular Cancer 237.

Miquet JG, Sotelo AI, Bartke A \& Turyn D 2004 Suppression of growth hormone (GH) Janus tyrosine kinase 2/signal transducer and activator of transcription 5 signaling pathway in transgenic mice overexpressing bovine GH. Endocrinology 145 2824-2832.

Moutoussamy S, Kelly PA \& Finidori J 1998 Growth-hormone-receptor and cytokine-receptor-family signaling. European Journal of Biochemistry $2551-11$.

Nemeth E, Valore EV, Territo M, Schiller G, Lichtenstein A \& Ganz T 2003 Hepcidin, a putative mediator of anemia of inflammation, is a type II acute-phase protein. Blood 101 2461-2463.

Nicolas G, Chauvet C, Viatte L, Danan JL, Bigard X, Devaux I, Beaumont C, Kahn A \& Vaulont S 2002 gene encoding the iron regulatory peptide hepcidin is regulated by anemia, hypoxia, and inflammation. Journal of Clinical Investigation 110 1037-1044.
Nishizaki Y, Shimazu K, Kondoh H \& Sasaki H 2001 Identification of essential sequence motifs in the node-notochord enhancer of Foxa2 $(H n f 3 \beta)$ gene that are conserved across vertebrate species. Mechanisms of Development 102 57-66.

Olsson B, Bohlooly-Y M, Brusehed O, Isaksson OGP, Ahrén B, Olofsson SO, Oscarsson J \& Törnell J 2003 Bovine growth hormonetransgenic mice have major alterations in hepatic expression of metabolic genes. American Journal of Physiology - Endocrinology and Metabolism 285 E504-E511.

Orian JM, Snibson K, Stevenson JL, Brandon MR \& Herington AC 1991 Elevation of growth hormone $\mathrm{GH}$ and prolactin receptors in transgenic mice expressing ovine GH. Endocrinology 128 1238-1246.

Park CH, Valore EV, Waring AJ \& Ganz T 2001 Hepcidin, a urinary antimicrobial peptide synthesized in the liver. Journal of Biological Chemistry 276 7806-7810.

Pfaffl MW 2001 A new mathematical model for relative quantification in real-time RT-PCR. Nucleic Acids Research 29 e 45.

Pigeon C, Ilyin G, Courselaud B, Leroyer P, Turlin B, Brissot P \& Loréal O 2001 A new mouse liver-specific gene, encoding a protein homologous to human antimicrobial peptide hepcidin, is overexpressed during iron overload. Journal of Biological Chemistry 276 7811-7819.

Puskas F, Gergely P, Banki K \& Perl A 2000 Stimulation of the pentose phosphate pathway and glutathione levels by dehydroascorbate, the oxidized form of vitamin C. FASEB Journal 14 1352-1360.

Ramelot TA, Cort JR, Goldsmith-Fischman S, Kornhaber GJ, Xiao R, Shastry R, Acton TB, Honig B, Montelione GT \& Kennedy MA 2004 Solution NMR structure of the iron-sulfur cluster assembly protein $\mathrm{U}$ (IscU) with zinc bound at the active site. Journal of Molecular Biology 344 567-583.

Rausa FM, Tan Y, Zhou H, Yoo KW, Stolz DB, Watkins SC, Franks RR, Unterman TG \& Costa RH 2000 Elevated levels of hepatocyte nuclear factor $3 \beta$ in mouse hepatocytes influence expression of genes involved in bile acid and glucose homeostasis. Molecular and Cellular Biology 20 8264-8282.

Rise ML, Jones SRM, Brown GD, von Schalburg KR, Davidson WS \& Koop BF 2004a Microarray analyses identify molecular biomarkers of Atlantic salmon macrophage and hematopoietic kidney response to Piscirickettsia salmonis infection. Physiological Genomics 20 21-35.

Rise ML, von Schalburg KR, Brown GD, Mawer MA, Devlin RH, Kuipers N, Busby M, Beetz-Sargent M, Alberto R, Gibbs AR et al. $2004 b$ Development and application of a salmonid EST database and CDNA microarray: data mining and interspecific hybridization characteristics. Genome Research 14 478-490.

Schilke B, Voisine C, Beinert H \& Craig E 1999 Evidence for a conserved system for iron metabolism in the mitochondria of Saccharomyces cerevisiae. PNAS 96 10206-10211.

Sharma N, Butterworth J, Cooper BT, Tselepis C \& Iqbal TH 2005 Emerging role of the liver in iron metabolism. American Journal of Gastroenterology 100 201-206.

Shike H, Lauth X, Westerman ME, Ostland VE, Carlberg JM, Van Olst JC, Shimizu C, Bulet P \& Burns JC 2002 Bass hepcidin is a novel antimicrobial peptide induced by bacterial challenge. European Journal of Biochemistry 269 2232-2237.

Shike H, Shimizu C, Lauth X \& Burns JC 2004 Organization and expression analysis of the zebrafish hepcidin gene, an antimicrobial peptide gene conserved among vertebrates. Developmental and Comparative Immunology 28 747-754.

Shiu RPC, Pouyssegur J \& Pastan I 1977 Glucose depletion accounts for the induction of two transformation-sensitive membrane proteins in Rous sarcoma virus-transformed chick embryo fibroblasts. PNAS 74 3840-3844.

Stangler T, Mayr LM \& Willbold D 2002 Solution structure of human $\mathrm{GABA}_{\mathrm{A}}$ receptor-associated protein GABARAP. Journal of Biological Chemistry 277 13363-13366.

Stevens ED \& Devlin RH 2000 Intestinal morphology in growth hormone transgenic coho salmon. Journal of Fish Biology 56 191-195. 
Stevens ED \& Devlin RH 2005 Is enhancement of digestive capacity a direct effect of GH transgenesis or an indirect effect of enhanced appetite? Journal of Fish Biology 66 1-16.

Suri C, Haremaki T \& Weinstein DC 2004 Inhibition of mesodermal fate by Xenopus HNF3ß/FoxA2. Developmental Biology 265 90-104.

Thomas-Jones E, Thorpe K, Harrison N, Thomas G, Morris C, Hutchinson T, Woodhead S \& Tyler C 2003 Dynamics of estrogen biomarker responses in rainbow trout exposed to 17beta-estradiol and 17alpha-ethinylestradiol. Environmental Toxicology and Chemistry 22 3001-3008.

Thompson BJL, Shang CA \& Waters MJ 2000 Identification of genes induced by growth hormone in rat liver using cDNA arrays. Endocrinology 141 4321-4324.

Tivesten Å, Barlind A, Caidahl K, Klintland N, Cittadini A, Ohlsson C \& Isgaard J 2004 Growth hormone-induced blood pressure decrease is associated with increased mRNA levels of the vascular smooth muscle $\mathrm{K}_{\mathrm{ATP}}$ channel. Journal of Endocrinology 183 195-202.

Tong W \& Rouault T 2000 Distinct iron-sulfur cluster assembly complexes exist in the cytosol and mitochondria of human cells. EMBO Journal 19 5692-5700.

Tsuchiya T, Dhahbi JM, Cui X, Mote PL, Bartke A \& Spindler SR 2004 Additive regulation of hepatic gene expression by dwarfism and caloric restriction. Physiological Genomics 17 307-315.

Tusher VG, Tibshirani R \& Chu G 2001 Significance analysis of microarrays applied to the ionizing radiation response. PNAS 98 5116-5121.

Vasseur S, Mallo GV, Fiedler F, Bödeker H, Cánepa E, Moreno S \& Iovanna JL 1999 Cloning and expression of the human p8, a nuclear protein with mitogenic activity. European Journal of Biochemistry 259 670-675.
Vasseur S, Hoffmeister A, Garcia-Montero A, Mallo GV, Feil R, Kuhbandner S, Dagorn JC \& Iovanna JL 2002 p8-Deficient fibroblasts grow more rapidly and are more resistant to adriamycininduced apoptosis. Oncogene 21 1685-1694.

von Schalburg KR, Rise ML, Brown GD, Davidson WS \& Koop BF $2005 a$ A comprehensive survey of the genes involved in maturation and development of the rainbow trout ovary. Biology of Reproduction 72 687-699.

von Schalburg KR, Rise ML, Cooper GA, Brown GD, Gibbs AR, Nelson CC, Davidson WS \& Koop BF $2005 b$ Fish and chips: various methodologies demonstrate utility of a 16006 -gene salmonid microarray. BioMed Central Genomics 6126.

Wang H, Bedford FK, Brandon NJ, Moss SJ \& Olsen RW 1999 GABA(A)-receptor-associated protein links GABA(A) receptors and the cytoskeleton. Nature 397 69-72.

Wu FS, Park Y, Roufa D \& Martonosi A 1981 Selective stimulation of the synthesis of an 80000 -dalton protein by calcium ionophores. Journal of Biological Chemistry 256 5309-5312.

Zheng L, Cash VL, Flint DH \& Dean DR 1998 Assembly of ironsulfur clusters. Identification of an iscSUA-hscBA-fdx gene cluster from Azotobacter vinelandii. Journal of Biological Chemistry 273 13264-13272.

Zinke I, Schütz CS, Katzenberger JD, Bauer M \& Pankratz MJ 2002 Nutrient control of gene expression in Drosophila: microarray analysis of starvation and sugar-dependent response. EMBO Journal 21 6162-6173.

Received in final form 13 April 2006

Accepted 26 May 2006

Made available online as an Accepted Preprint 5 June 2006 